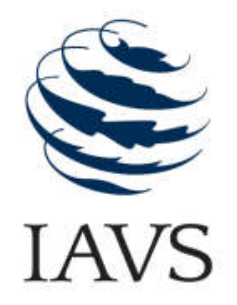

( )

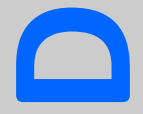

2

10

- 0

(2) 음

(ก) $\frac{\pi}{4}$

$\rightarrow 4$

$1 \frac{1}{0}$

(1) ลั

(1) $\frac{\frac{\pi}{\pi}}{n}$

는

U

0

0 단

- 4

1

4 윽

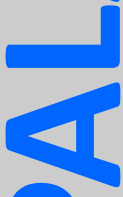

Q 


\section{Table of Contents}

Editorial

News

Peregrym, M. et al. The impact of Artificial Light At Night (ALAN) on the National Nature Parks, Biosphere and Nature Reserves of the Steppe Zone and Crimean Mountains within Ukraine

Short Contribution

Photo Story

Book Review

\section{Recent Publications of our} Members

Forthcoming Events

23

24

\section{Palaearctic Grasslands}

ISSN 1868-2456

DOI 10.21570/EDGG.PG39

Palaearctic Grasslands, formerly published under the names Bulletin of the European Dry Grassland Group (Issues 1-26) and Bulletin of the Eurasian Dry Grassland Group (Issues 27-37) is the journal of the Eurasian Dry Grassland Group (EDGG). It usually appears in four issues per year. Palaearctic Grasslands publishes news and announcements of EDGG, its projects, related organisations and its members. At the same time it serves as outlet for scientific articles and photo contributions.

Palaearctic Grasslands is sent to all EDGG members of the group and, together with all previous issues, it is also freely available at http://www.edgg.org/ publications.htm.

The copyright of the included texts, photographs, and other figures remains with their authors. If you wish to re-use them or parts of them, please, obtain the written consent of the authors first.

Scientific articles (Research Articles, Reviews, Forum Articles, Scientific Reports) should be submitted to Jürgen Dengler (juergen.dengler@uni-bayreuth.de), following the Author Guidelines published in Palaearctic Grasslands 37, 6-8. They are subject to editorial review, with one member of the Editorial Board serving as Scientific Editor and deciding about acceptance, necessary revisions or rejection.

All other text contributions (News, Announcements, Short Contributions, Book Reviews,...) should be submitted to Anna Kuzemko (anyameadow.ak@gmail.com) AND Idoia Biurrun (idoia.biurrun@ehu.es). Please check a current issue of Palaearctic Grasslands for the format and style. Deadline for submission to the next issue is 20 January 2019

Photo contributions (photos for general illustrative purposes with captions; proposals for Photo Stories; candidate photos for the Photo Competition) should be submitted to both Photo Editors, Rocco Labadessa (rocco.labadessa@gmail.com) AND Jalil Noroozi (noroozi.jalil@gmail.com). Deadline for submissions to the next Photo Competition on "Grassland people" is 20 January 2019.

Contributions to the sections "Recent Publications of our Members" and "Forthcoming Events" should be sent to Iwona Dembicz (iwodem@op.pl).

Photos included in submissions have always to be delivered in two forms, embedded in the document and as separate jpg (or tiff) files with sufficient resolution for printing (i.e. not less than $1 \mathrm{MB}$ ).

\section{Editorial Board}

CHIEF EDITOR:

Anna Kuzemko, Ukraine

DEPUTY CHIEF EDITORS:

Idoia Biurrun, Spain Jürgen Dengler, Switzerland

\section{EDITORAL BOARD:}

Dolores Byrne, Ireland Iwona Dembicz, Poland

Edy Fantinato, Italy Magdalena Firganek-Fulcher, UK Paul Goriup, UK Riccardo Guarino, Italy Richard Jefferson, UK Gwyn Jones, UK
Rocco Labadessa, Italy

Ashley Lyons, UK Lorna Marcham, UK Jim Martin, Ireland James Moran, Ireland Jalil Noroozi, Austria Arkadiusz Nowak, Poland Salza Palpurina, Bulgaria Nina Polchaninova, Ukraine Solvita Rūsina, Latvia Stuart Smith, UK Laura Sutcliffe, Germany Péter Török, Hungary Atushi Ushimaru, Japan Orsolya Valkó, Hungary Stephen Venn, Finland 


\section{Editorial}

Dear readers,

We are pleased to present a new issue of Palaearctic Grasslands, the last in 2018. In this issue, we provide updated information on the representativeness of different countries within the Palaearctic realm among the members of the EDGG. Two new members joined our team - Lorna and Richard, who took over the functions of Linguistic Editors. Their vision of the further development of Palaearctic Grasslands, as well as a map of the density of the group members, can be found on page 4.

Our Photo Editors Rocco and Jalil continue to work actively not only on illustrating the journal with beautiful photographs, but also on preparing the sections "Photo Story" and "Photo Competition". This information is presented on page 5 .

Special issues of scientific journals are an important part of EDGG activities, so pay attention to the fact that you still have the opportunity to submit abstracts for possible publication in the Special Issue of Flora on Ecology and Evolution of Steppe Biodiversity in collaboration with EDGG (see announcement on page 6). On page 7 you can find information about the recently published 13th EDGG Special Feature of Tuexenia on Conservation, management and restoration of seminatural and natural grasslands in Central Europe.

The main material of the current issue is an article about a little-studied impact of artificial light at night (ALAN) on protected areas of Ukraine, which was prepared with the cooperation of Ukrainian and Hungarian scientists (pp. 8-14). A "Short Contribution" on the $90^{\text {th }}$ anniversary of the Ukrainian steppe reserve also concerns protected steppe areas of Ukraine (pp. 15-16).

In the "Photo Story" section you can enjoy beautiful photos of the plant world of ancient burial mounds - kurgans of the Carpathian basin in the Hungarian lowlands. And, of course, under our traditional headings "Book Review", "Recent Pub- lications of our Members" and "Forthcoming Events" you can find a lot of useful information.

We wish you a pleasant reading on the eves of Christmas and the New Year, we hope that you will productively spend the winter processing material from the last field season and some of these results will appear next year on the pages of Palaearctic Grasslands.

Anna Kuzemko, Chief Editor (anyameadow.ak@gmail.com)

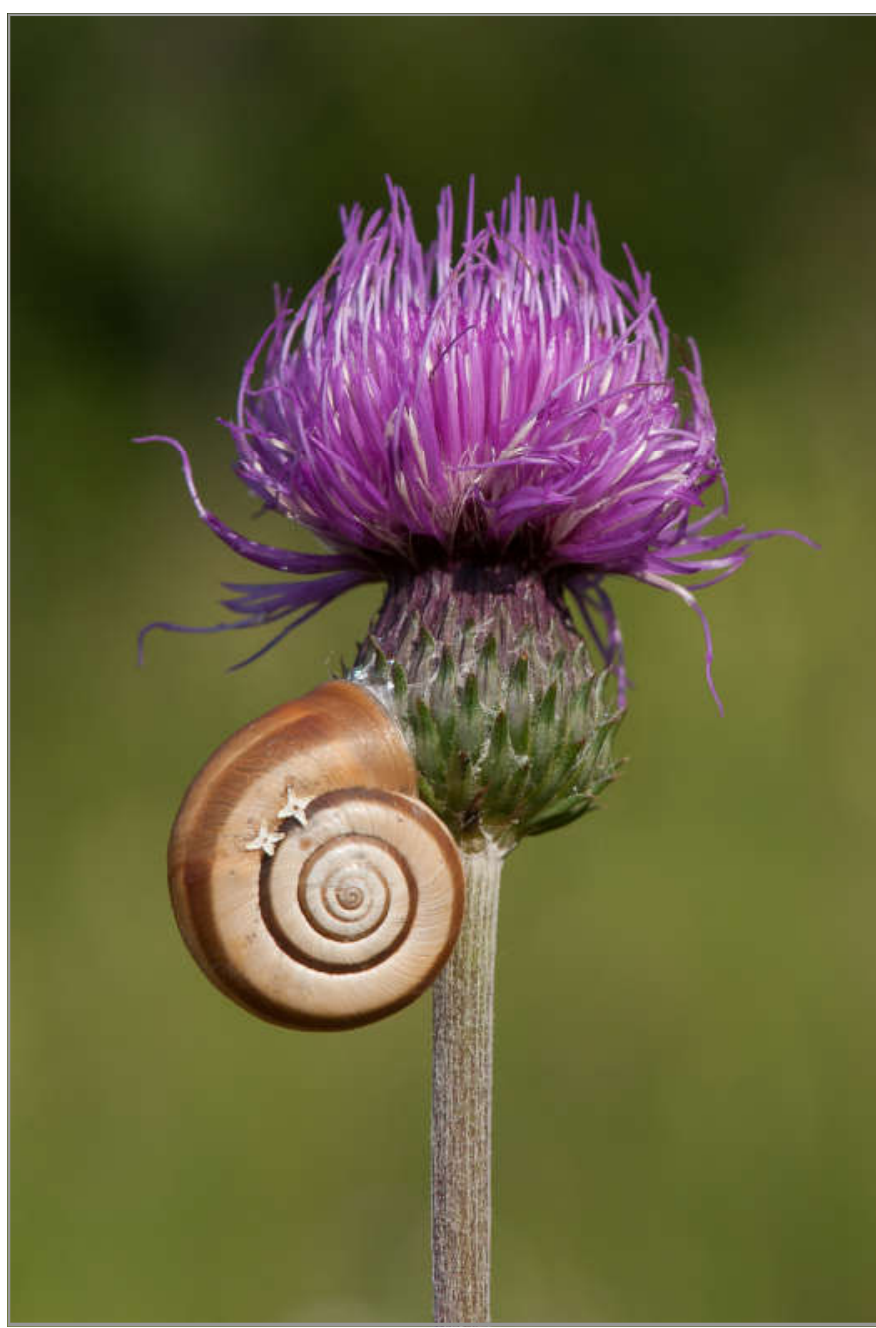

Galium flowers on a land snail (probably Helicella itala) on Cirsium tuberosum in a semi-dry grassland in Navarre, Spain. Photo: J. Dengler. 


\section{News}

\section{Density of EDGG members}

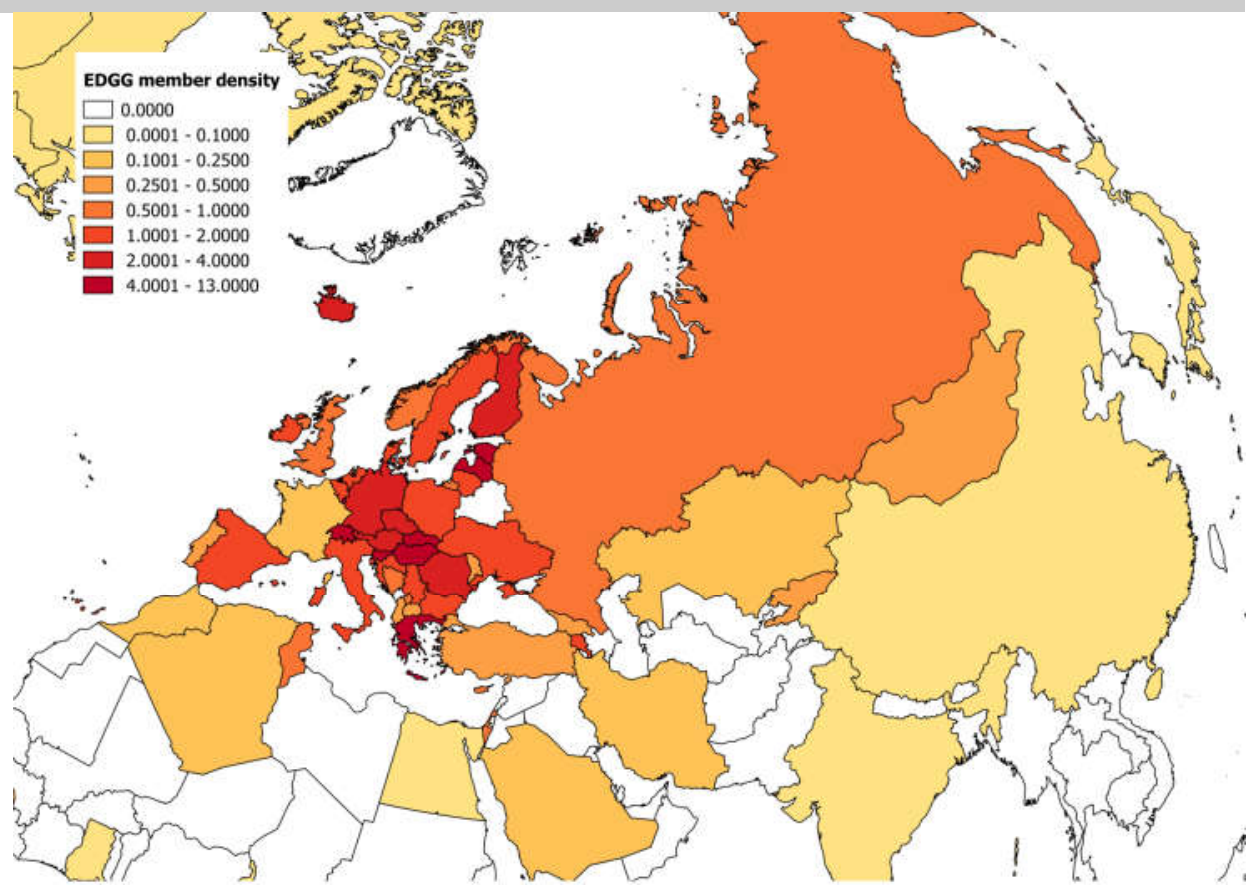

On 27 November 2018, the Eurasian Dry Grassland Group had 1,323 members, with an average increment of 118 members per year. All the continents of the world are represented, except for Antarctica, with members coming from 67 different countries. Countries with the highest number of members are Germany, Greece and Italy, with 262, 125 and 78 members, respectively. However, when member density per million inhabitants is concerned, the top three positions are occupied by Estonia, Greece and Latvia, with 12.91, 11.60 and 8.20 EDGG members per million inhabitants, respectively.

We encourage new members from all over the Palaearctic realm to join the Eurasian Dry Grassland Group. Researchers from underrepresented areas like the North Africa, the Middle East, Middle, Central and East Asia are especially welcome!

Edy Fantinato

\section{Board of Palaearctic Grasslands is still growing}

Our editorial board continues to grow. We are pleased to introduce two new linguistic editors - Lorna and Richard and their vision of the future development of the Palaearctic Grasslands.

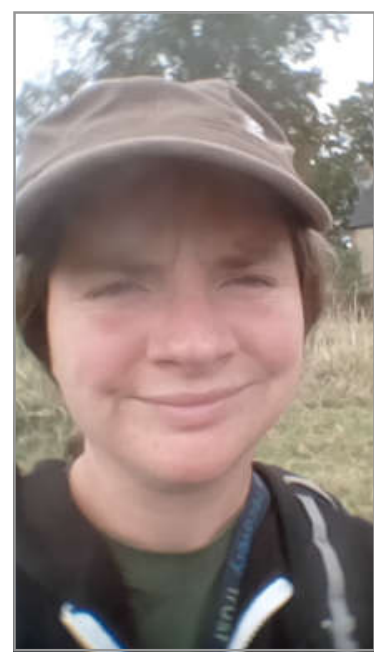

I would like to see Palaearctic Grasslands develop into a highly respected repository for the publication of high quality articles on Palaearctic grasslands. It would also be good to encourage the submission of more articles with a nature conservation theme and possibly papers on aspects of the fauna of semi-natural grasslands.

Richard Jefferson

I hope the journal will provide information and inspiration for exciting new collaborations in research and conservation, by being informative, professional, accessible and beautiful.

Lorna Marcham

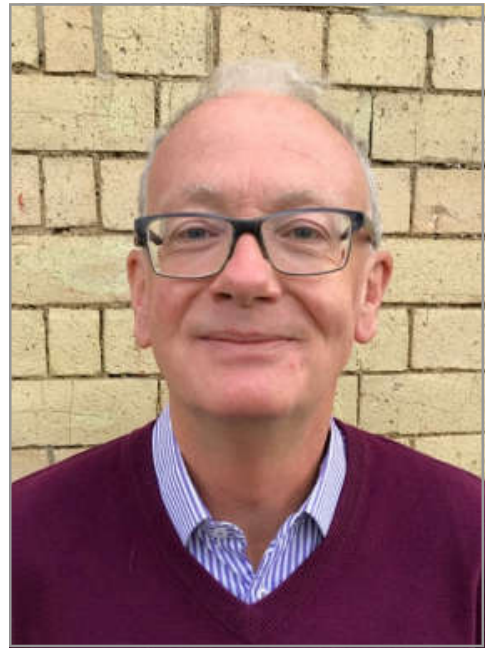




\section{Photo Story and Photo Competition}

In this issue we are pleased to announce the third call for the sections "Photo Story" and "Photo Competition", devoted to the beauty of Palaearctic grasslands.

Photo Story is an open space where members can submit their own photo collection on a certain grassland-related topic of their choice. High-quality photos should be provided together with their captions (at least species names or landscape description), a brief text and possibly other graphical elements (like a map or a drawing). The selection of photos should fit for 1-4 pages and the proponents should already propose a preliminary layout (in PDF or MS Word format), which will be finally typeset by Editors. As an example, you may take a look at the Photo Story at pages 17-20.

Photo Competition is a call for grassland enthusiasts, who can challenge each other on a predefined grassland theme.

The theme of next EDGG Photo Competition is "Grassland people", dedicated to the role of indigenous women and men as key actors in local grassland ecosystems.

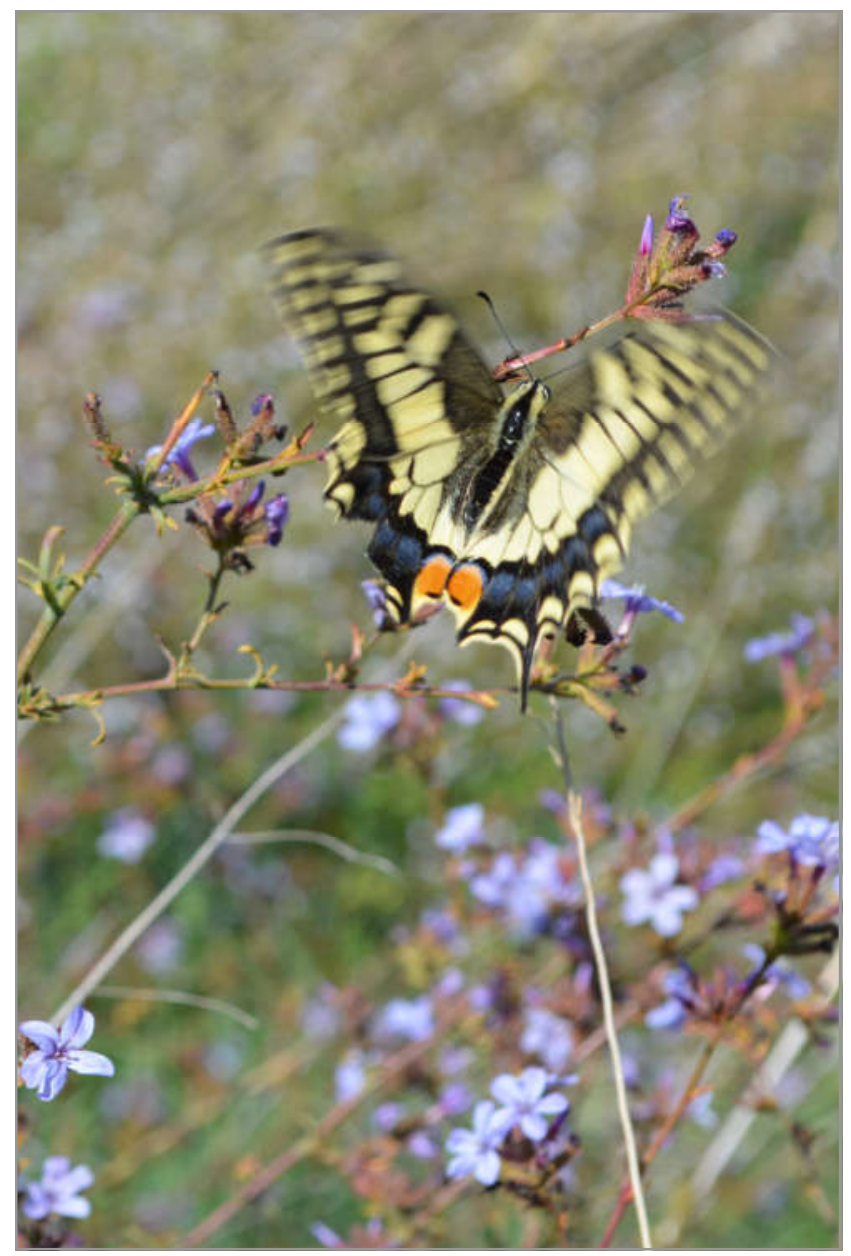

Papilio machaon feeding on Plumbago europaea in grasslands of Natura 2000 site "Murgia Alta", southern Italy. Photo: R. Labadessa.
You are invited to send up to three high-quality photographs within the competition theme (full size JPEG or TIFF images, at least $300 \mathrm{dpi}$ ) together with captions giving information on the subject (species name, date, place name) and, possibly, technical details (camera, lens, aperture and exposure time). The selection will be made by a jury of at least five members from the Editorial Board of the journal. The three best shots will be awarded with full space in the next issue, but we reserve the right to use further submitted photos for illustrative purposes in other parts of the issue.

If you feel you can contribute with your shots, don't be shy! Everyone can join the competition without the need of being a professional photographer!

If you want to contribute to Photo Story or Photo Competition (next deadline 20 January 2019), or if you simply want your photographs published in the journal, please submit them together with required information to Rocco (rocco.labadessa@gmail.com) and Jalil (noroozi.jalil@gmail.com).

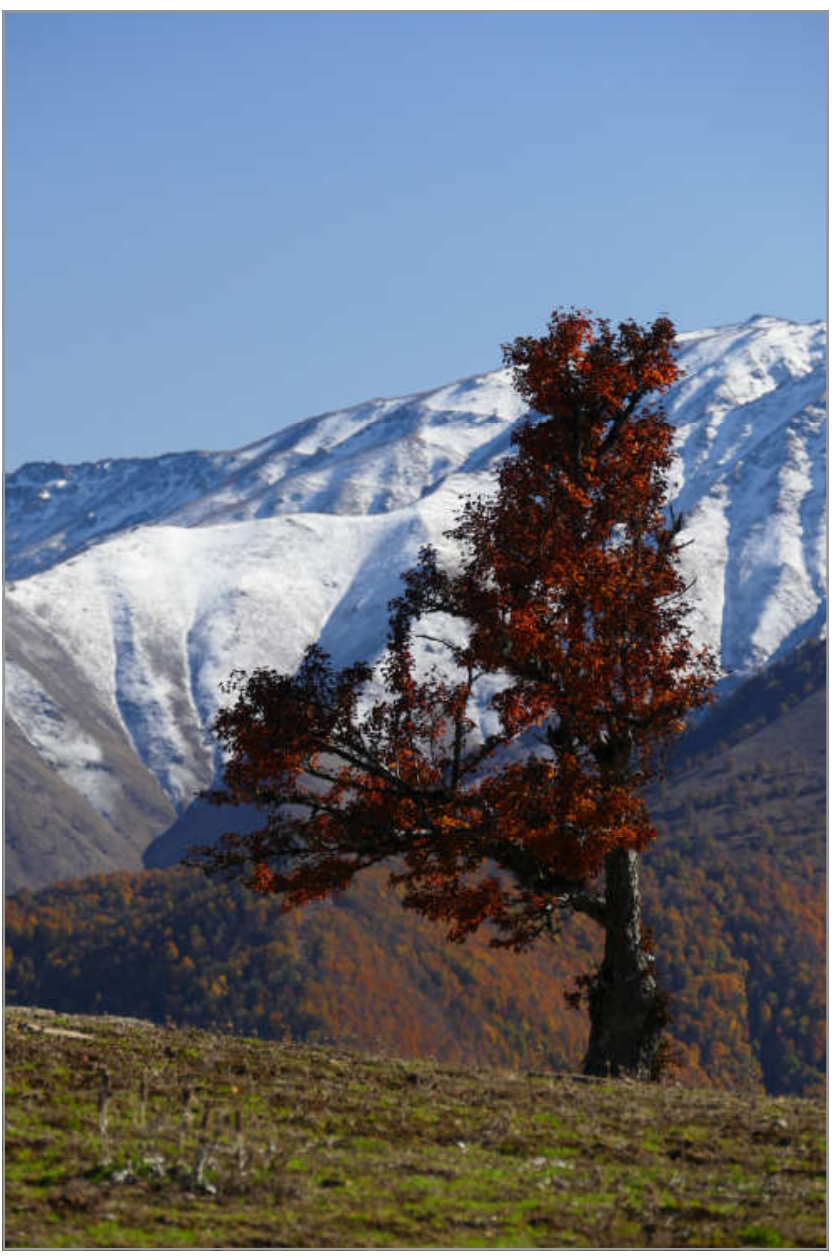

Subalpine grasslands of northern slopes of Central Alborz. Photo: J. Noroozi. 


\title{
EDGG Publication
}

\section{Announcement of a Special Issue organized in the journal FLORA in collaboration with EDGG on Ecology and Evolution of Steppe Biodiversity}

\author{
Guest editors \\ Péter Török (University of Debrecen, Hungary), \\ Barbara Neuffer (University of Osnabrück, Germany) \\ Karl Georg Bernhardt (Universität für Bodenkultur, Austria) \\ Karsten Wesche (Senckenberg Museum of Natural History, Germany)
}

Palaearctic steppes are the largest continuous terrestrial natural habitats of the world with high biodiversity at multiple scales. Steppe grasslands and adjacent forest steppes are key elements of natural vegetation in vast landscapes from Central and Eastern Europe to Northern China, spanning across the whole temperate zone of Eurasia and similar habitats in North Africa, Anatolia, and Iran. Steppes offer globally unique options for studies on biological patterns in a relatively homogeneous, yet spatially most extensive biome. Examples include evolution of biodiversity on a continental scale, effects of large climatic gradients on species performance, or ecosystem functioning under extreme and very variable conditions. Because typical steppes are characterized by fertile soils, they are subjected to large-scale degradation and area loss by intensive crop production or other forms of overuse especially in the Western part of their distribution zone. Conservation and restoration of steppe biodiversity have been identified as key priority for research and practice. Effective and sustainable steppe management does, however, depend on sound knowledge of the ecological properties and background mechanisms which are responsible for the sustainment of crucial ecological functions and services in pristine steppes. In this special issue we aim to give high emphasis on the most recent and novel research in steppe biodiversity and ecology. We thus invite studies dealing with any aspects of plant community ecology, plant traits, fire ecology, plant phenology, plant ecophysiology, plant reproductive biology, population genetics, ecological interactions, conservation, plant chorology and ecosystem functioning related to steppe ecosystems.

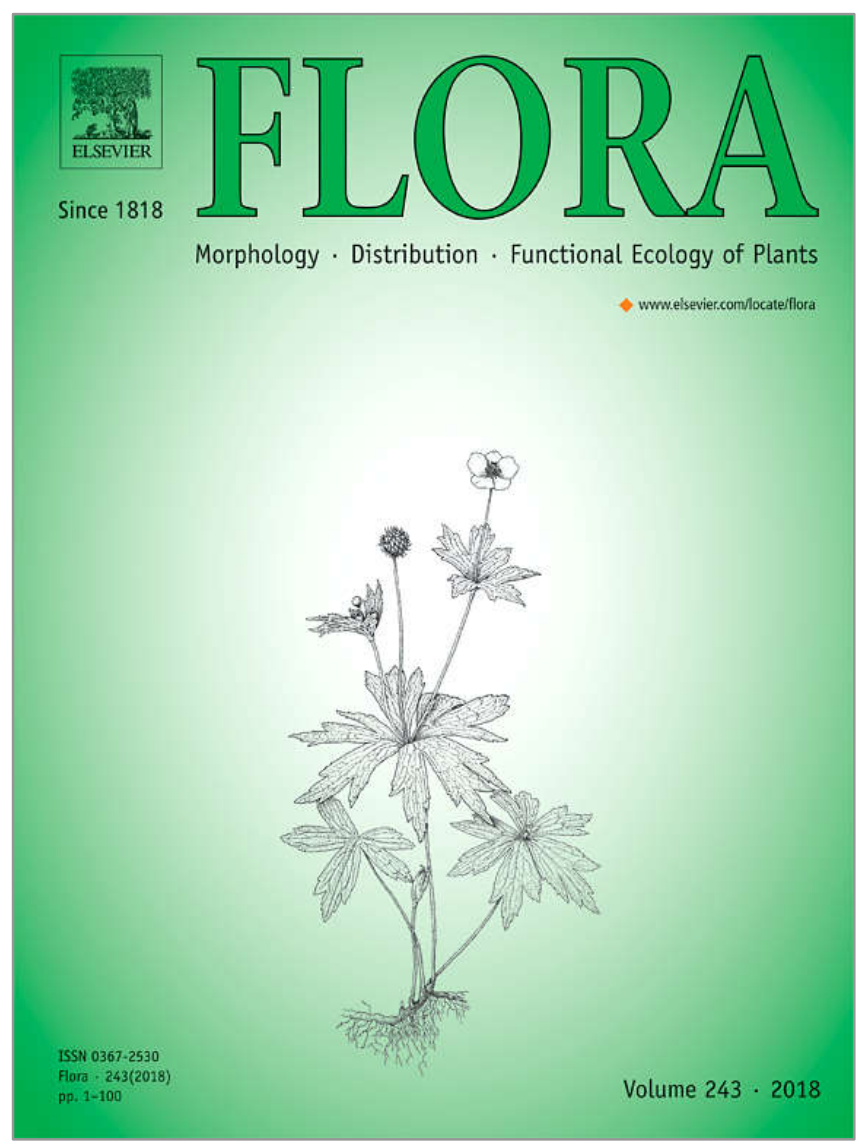

Please submit your abstracts (up to $\mathbf{3 0 0}$ words and one page with authors and affiliations) by December 15, 2018 to Peter Török (molinia@gmail.com) for evaluation. 


\section{Conservation, management and restoration of semi- natural and natural grasslands in Central Europe - the $13^{\text {th }}$ EDGG Special Feature in Tuexenia has been published}

The $13^{\text {th }}$ EDGG Special Feature in Tuexenia complements the series of special features devoted to Palaearctic steppes and semi-natural grasslands. It focuses on the conservation, management, restoration and biodiversity of semi-natural and natural grasslands in Central Europe. It was edited by Balázs Deák, Thomas Becker, Steffen Boch and Viktoria Wagner (Deák et al. 2018). Altogether 43 authors from six countries (Bulgaria, Germany, Hungary, Romania, Slovakia, Switzerland and Ukraine) contributed to the published papers.

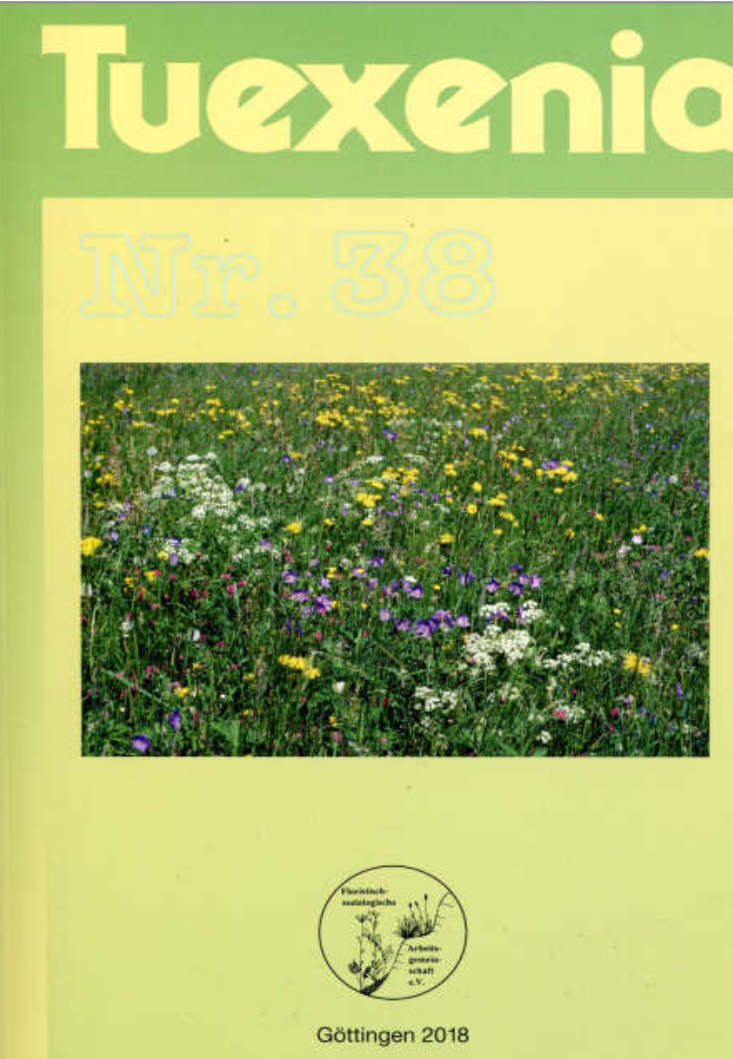

The paper of Boch et al. (2018) investigates the effects of grazing management on the species richness of bryophyte species in mesic grasslands. Bódis et al. (2018) studied the habitat preferences of the endangered lizard-orchid $\mathrm{Hi}$ mantoglossum adriaticum. The paper of Bittnerová et al. (2018) deals with the patterns of aboveground vegetation and soil seed bank along a successional gradient from grassland to forest. Didukh \& Vasheniak (2018) described the vegetation of limestone outcrops in Podillia (Ukraine).
Molnár et al. (2018) studied the factors influencing the distribution of the endangered Sternbergia colchiciflora in grassland habitats preserved in Pannonian cemeteries. Sopotlieva et al. (2018) revealed the ecosystem conditions of Bulgarian grasslands located outside the Natura 2000 network. Szabó \& Ruprecht (2018) finally highlight the potential of seed banks in the recovery of Stipa-dominated and steppe-like dry grasslands.

The publications are all open access and freely available from the journal website at http://www.zobodat.at/ publikation_series.php?id=20993. They will also be available in the near future from the re-launched EDGG website.

\section{Contributions in the Special Feature}

Bittnerová, S., Ujházy, K., Hegedüšová, K., Škodová, I., Ujházyová, M. \& Janišová, M. 2018. Soil seed bank and above-ground vegetation changes during grassland succession: Is space-fortime substitution an alternative to re-sampling? Tuexenia 38 : 347-370.

Boch, S., Müller, J., Prati, D. \& Fischer, M. 2018. Low-intensity management promotes bryophyte diversity in grasslands. Tuexenia 38: 311-328.

Bódis, B., Biró, É., Nagy, T., Takács, A., Molnár, V.A. \& Lukács, B.A. 2018. Habitat preferences of the rare lizard-orchid Himantoglossum adriaticum $\mathrm{H}$. Baumann. Tuexenia 38: 329345.

Deák, B., Becker, T., Boch, S. \& Wagner, V. 2018. Conservation, management and restoration of semi-natural and natural grasslands in Central Europe - Editorial to the 13th EDGG Special Feature. Tuexenia 38: 305-310.

Didukh, Y.P. \& Vasheniak, Y.A. 2018. Vegetation of limestone outcrops in Western and Central Podillia (Ukraine). Tuexenia 38: 419-444.

Molnár, V.A., Mészáros, A., Csathó, A.I., Balogh, G., Takács, A., Löki, V., Lovas-Kiss, A., Tökölyi, J., Somlyay, L. \& Bauer, N. 2018. Distribution and seed production of the rare, dry grassland specialist Sternbergia colchiciflora (Amaryllidaceae) in Pannonian cemeteries. Tuexenia 38: 371-384.

Sopotlieva, D., Velev, N., Tsvetkova, N., Vassilev, V. \& Apostolova, I. 2018. Ecosystem condition assessment of semi-natural grasslands outside the Natura 2000 network in Bulgaria, using vegetation data. Tuexenia 38: 385-404.

Szabó, A. \& Ruprecht, E. 2018. Restoration possibilities of dry grasslands afforested by pine: the role of seed bank and remnant vegetation. Tuexenia 38: 405-418.

Balázs Deák, Debrecen, Hungary (debalazs@gmail.com) Thomas Becker, Trier, Germany (beckerth@uni-trier.de) 


\title{
The impact of artificial light at night (ALAN) on the Na- tional Nature Parks, Biosphere and Nature Reserves of the Steppe Zone and Crimean Mountains within Ukraine
}

\author{
Mykyta Peregrym $^{1 *}$, Erika Pénzesné Kónya $^{1}$ \& Oleksiy Vasyliuk ${ }^{2}$
}

\begin{abstract}
${ }^{1}$ Eszterházy Károly University of Applied Sciences, Leanyka Str., 6, Eger, 3300, Hungary, mykyta.peregrym@uni-eszterhazy.hu (M. Peregrym), konya.erika@uni-eszterhazy.hu (E. Pénzesné Kónya)

${ }^{2}$ NGO "Ukrainian Nature Conservation Group", Hoholya Str., 40, Vasylkiv, Kyiv region, 08600, Ukraine; vasyliuk@gmail.com
\end{abstract}

*) Corresponding author: mykyta.peregrym @uni-eszterhazy.hu

Palaearctic Grasslands 39 (2018): 8-14

Abstract: Artificial light at night (ALAN) and sky glow are a recognized anthropogenic pressure, but the consequences of this pressure on protected areas within Ukraine are unclear. This research attempted to estimate the level of light pollution on the protected territories of the National Nature Parks (NNPs), Biosphere and Nature Reserves in the Steppe Zone and Crimea Mountains of Ukraine. Kmz layers of these protected territories and the New World Atlas of Artificial Sky Brightness, through Google Earth Pro, were used to calculate the level of artificial sky brightness for 15 NNPs, three Biosphere Reserves and 10 Nature Reserves. The results show that even some of the most protected areas within the Steppe Zone and Crimean Mountains are impacted by ALAN. Of the studied protected areas $44.2 \%$ have a natural dark night sky, $40.1 \%$ have artificial brightness ranging between 8 and $16 \%$, and the remainder $(15.7 \%)$ are polluted with an artificial brightness greater than $16 \%$. Areas with light pollution greater than $16 \%$ are often situated near big cities or industrial centers. It was noted that light pollution levels were not taken into account during the creation of any protected areas within Ukraine.

Keywords: artificial light at night (ALAN); Crimea; light pollution; nature conservation; protected area; sky glow; steppe; Ukraine.

Abbreviations: ALAN = artificial light at night; NNP = National Nature Park.

Submitted: 24 August 2018; first decision: 19 September 2018; accepted: 21 October 2018

Scientific Editor: Péter Török

Linguistic Editor: Jim Martin

\section{Introduction}

The Ukrainian steppes is a habitat that has declined in area over the last 300 years, decreasing from approximately $40 \%$ of the modern territory of Ukraine to the current situation where only about $3 \%$ of the natural and seminatural steppes remain (Korotchenko \& Peregrym 2012; Kolomytsev \& Vasyliuk 2013; Wesche et al. 2016). The Steppe Zone and Crimean Mountains are two areas within Ukraine where steppe ecosystems are still widely distributed. Unfortunately, anthropogenic pressures, such as plowing, burning, and afforestation (Burkovskyi et al. 2013), continue to impact on the remaining areas of seminatural steppe vegetation, as is the case for many seminatural systems across Europe (Dengler et al. 2014; Török \& Dengler 2018; Török et al. 2018). One of the more recent pressures on the Steppe Zone and Crimean Mountains is artificial light at night (ALAN).
Over the last decade research on the impact of light pollution from a biological, ecological, medical, sociological and economic perspective has been published (Longcore \& Rich 2004; Hölker et al. 2010; Navara \& Nelson 2012; Gaston at al. 2013; Gaston et al. 2014; Gaston \& Bennie 2014; Bennie et al. 2015b; Kurvers \& Hölker 2015; Falchi et al. 2016).

The direct study of the influence of ALAN on grasslands and their biodiversity is a new area of research. Research by Bennie et al. (2018) has demonstrated that ALAN can affect changes in grasslands, leading to significant differences in vegetation biomass and the cover of dominant plant species, as well as changes in flowering phenology. Phenological changes within trees under the influence of urban night light was first documented over 80 years ago (Matzke 1936; Schroeder 1945), and more recently research has been undertaken on the physiological responses of plants to artificial lighting (Briggs 2006) and its 
ecological effects (Bennie et al. 2016). Field experiments in Swiss ruderal meadows which were exposed to ALAN demonstrated that nocturnal pollinator behavior changed with visits to the species Cirsium oleraceum decreasing by $62 \%$ in illuminated plots and fruit production by a focal plant fell by $13 \%$ (Knop et al. 2017). ALAN has also been documented as a contributing factor to the global decline in insect populations (Macgregor at al. 2015; Hallmann et al. 2017; Grubisic et al. 2018). Moreover, light pollution can cause cascading effects in grasslands, restructuring ecological communities by modifying the interactions between species and impacting pollination and seed dispersal (Bennie et al. 2015a).

There are examples of grassland genera (e.g. Hesperis and Matthiola from the Brassicaceae and some Caryophyllaceae such as Dianthus and Silene) that are pollinated by nocturnal insects and it can be expected that ALAN would impact these genera and the grassland communities that they occur in. In addition, the flowers of some bulb species provide important shelter at night for insects, especially during cold spring periods. Within grasslands interactions between plants and nocturnal insects, such as moths (Frank 2006; van Langevelde et al. 2011; van Geffen et al. 2014, 2015), will be impacted by ALAN. It has also been shown that nocturnal mammals are impacted by ALAN (Beier 2006).

Considering the current status of the Ukrainian steppes, the high recreational load within the Crimean Mountains, and recent data on the impact of ALAN on biodiversity, we decided to investigate the level of light pollution on the National Nature Parks (NNPs) and Biosphere and Nature Reserves within these regions.

\section{Study area}

The research covers the Steppe Zone and the Crimean Mountains of Ukraine, both areas where steppe ecosystems are still widely distributed. The borders of these areas are considered according to Didukh \& Shelyah-Sosonko (2003) with clarifications by Mala (2016) for the Right-bank Ukraine. Within the study there are 15 NNPs (Azov-Syvash NNP, Dvorichna NNP, Dzharylgach NNP, Nyzhniodniprovsky NNP, Nyzhniodnistrovsky NNP, NNP "Biloberezhzhia Sviatoslava”, NNP “Buz'kyi Gard”, NNP “Charivna Havan'”, NNP "Homilshanski Forests", NNP "Meotyda", NNP "Oleshky Sands", NNP "Svyati Hory", NNP "Tuzlovs'ki Lymany", NNP "Velykyi Luh", Pryazovsky NPP), three Biosphere Reserves (Askania-Nova Biosphere Reserve, Black Sea Biosphere Reserve and Danubian Biosphere Reserve) and 10 Nature Reserves (Cape Martian Nature Reserve, Crimea Nature Reserve with the Swan islands branch, Dnieper-Oril Natural Reserve, Karadag Nature Reserve, Kazantyp Nature Reserve, Lugansk Natural Reserve (4 branches - "Provalsky Steppe", "Stanychno-Luganske", "Striltsivsky Steppe", "Triokhizbensky Steppe"), Nature Reserve "Yelanets Steppe", Opuk Nature Reserve, Ukrainian Steppe Nature Reserve (4 branches - "Khomutovsky Steppe", "Kamyani Mohyly", "Kreidyana Flora", "Kal'mius'ke"), Yalta Mountain
-Forest Nature Reserve) which are objects of our study (Fig. 1).

It is important to note that although steppe ecosystems often dominate protected territories the diversity of other habitats can also be high. For example, some NNPs and Reserves include marine areas (Dzharylgach NNP, Black Sea Biosphere Reserve, Karadag Nature Reserve etc.), or large forest massifs (NNP "Svyati Hory", NNP "Homilshanski Forests", Crimea Nature Reserve etc.). Unfortunately, there is an absence of detailed information on the total area of all habitats within NNPs, Biosphere and Nature Reserves of the Steppe Zone and Crimean Mountains. General information on the landscape diversity of all protected areas of the Lugansk region (Vasyliuk et al. 2012) is available, as is information on the distribution of steppe biotopes in the Lugansk region (Vasyliuk et al. 2012) is available, as is information on the distribution of steppe biotopes in the Kherson and Odesa regions (Shyriaieva et al. 2014a, 2014b), as well as inventory data on chalky steppes in Lugansk, Donetsk and Kharkiv regions (Krivohizha et al. 2014; Vasyliuk et al. 2014).

\section{Methods}

The study was carried out using available tools from Google Earth Pro (version 7.3.2.5487; https:// www.google.com/earth/). We used the New World Atlas of Artificial Sky Brightness in the form of a kmz (Keyhole Markup language Zipped) layer which was created by Falchi et al. (2016) and is available through its 3D Globe version (https://cires.colorado.edu/Artificial-light). GIS layers showing the borders of NNPs, Biosphere and Nature Reserves were received in $\mathrm{kmz}$ format from the working group on the improvement of activities in the field of nature conservation within the Ministry of Ecology and Natural Resources of Ukraine. Some of these data are available online (http://pzf.gis.kh.ua/ru/services/\#uanposm). We overlaid the GIS layer of the borders of the protected areas with the artificial sky brightness layer and counted the number of squares of each index of level of artificial sky brightness according to the legend of the atlas (Falchi et al. 2016). An example of the process for the NNP "Meotyda" is shown in Fig. 2.

\section{Results}

The results are presented in Table 1 . To quantify an error within the calculations, we have added two columns to Table 1, one column with the calculated area and the other with the official area (according to information from the Ministry of Ecology and Natural Resources of Ukraine; http://pzf.menr.gov.ua/) for every protected area. Although the highlighted discrepancy is generally not more than $5 \%$ it is more than $10 \%$ for Dzharylgach NNP and approximately $31 \%$ for the branch "Kal'mius'ke" of the Ukrainian Steppe Nature Reserve. Unfortunately, there is no satisfactory explanation for these two discrepancies and either the official data are incorrect, or there are mistakes in $\mathrm{kmz}$ layers. 


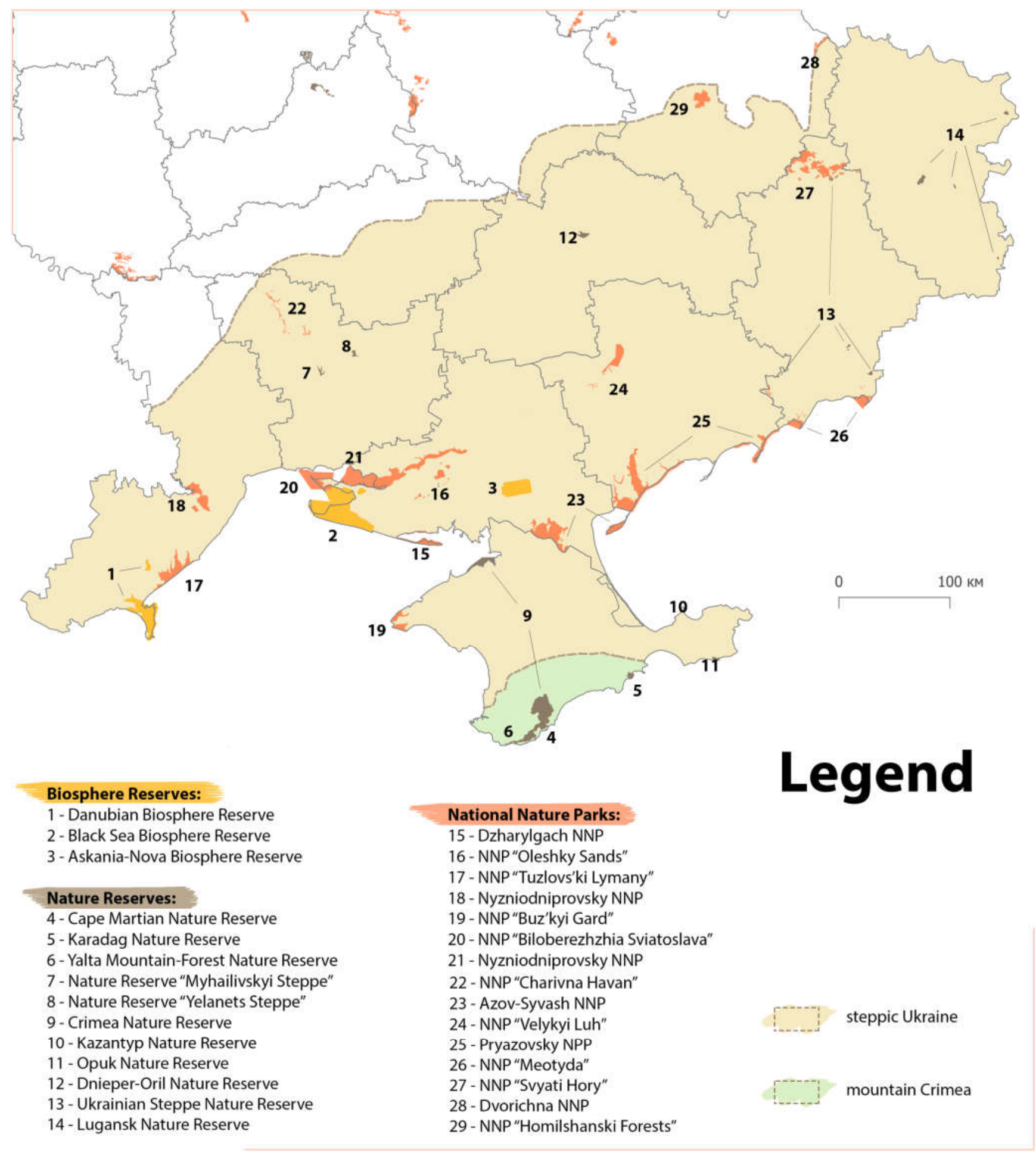

Fig. 1. National Nature Parks, Biosphere and Nature Reserves of the Steppe Zone and Crimean Mountains in Ukraine.

\section{Discussion}

We found that there is a widespread incursion of ALAN within the Steppe Zone and Crimea Mountains and these results correspond with the general situation for protected areas around the world (Gaston at al. 2015). Within Ukraine there are examples of protected areas with very low levels of artificial brightness that are less than $1 \%$, such as Azov-Syvash NNP and Danubian Biosphere Reserve (Table 1). Such low levels of light pollution are unique for
Europe. The New World Atlas of Artificial Sky Brightness shows that there are very high levels of light pollution across the continent: approximately $99 \%$ of the European population live under light-polluted skies; the Milky Way is hidden for $60 \%$ of Europeans; and $88 \%$ of Europe experiences light-polluted nights (Falchi et al. 2016). In general, the level of light pollution within protected areas in other European countries is higher and the rate of increase in light pollution is faster than for Ukraine (Gaston et al. 


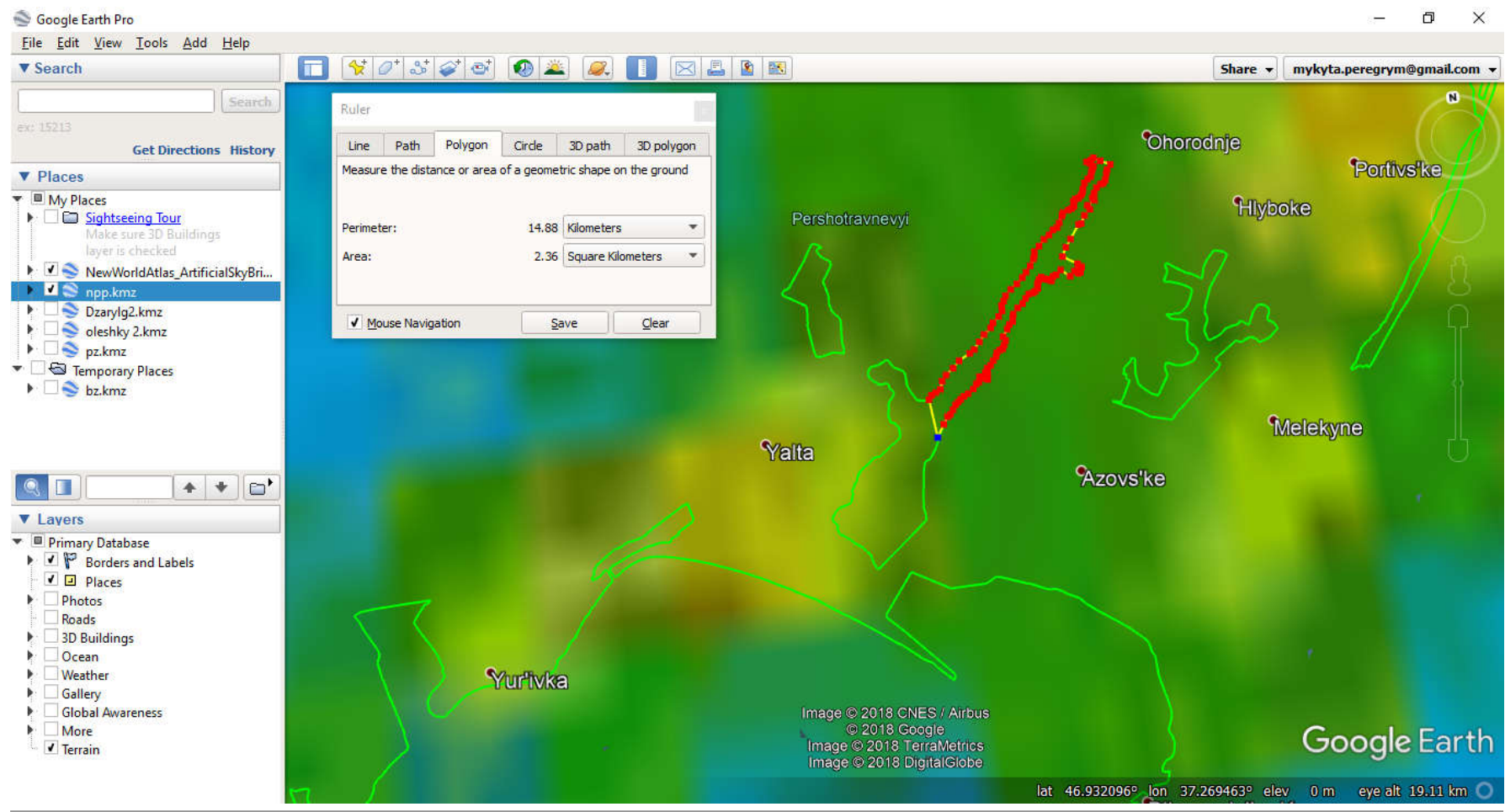

Fig. 2. An example of calculation of area $\left(\mathrm{km}^{2}\right)$ for every index of level of artificial sky brightness using Google Earth Pro and the kmz layer which was obtained from Falchi et al. (2016).

2015). The low levels of light pollution within areas of Ukraine can be attributed to economic and industrial decline after the collapse of the Soviet Union (Bennie et al. 2014).

The minimal level of artificial brightness which has a significant influence on biodiversity is unknown. However, a sky with light pollution between 8 and 16\% (from 6.96 to 55.7 $\mathrm{mcd} / \mathrm{m}^{2}$ ), can be considered polluted from an astronomical point of view (Falchi et al. 2016). This study has shown that $44.2 \%$ of the studied areas in Ukraine have a natural dark night sky. The night sky above $40.1 \%$ of the protected territories has an artificial brightness from 8 to $16 \%$, and the remainder $(15.7 \%)$ are light polluted by more than $16 \%$. These last areas are often situated near big cities or industrial centers. Also these urban areas have significantly higher air pollution levels that could be increasing the impact of the artificial brightness of the sky (McColgan 2003). It is important to note that the level of ALAN was not taken into account during the creation of any protected areas within Ukraine. We estimate that the level of light pollution in NNPs, Biosphere and Nature Reserves of the Steppe Zone and Crimea Mountains could be reduced with the development of educational and conservation strategies. As a first step, combating the direct sources of ALAN, such as street lights and lighting in buildings, should be initiated for protected areas and their surrounding areas. It is especially important to address light pollution surrounding nature reserves as these are often small areas with no buffer zone, as traditionally they were created for the conservation of specific species such as rare plants (Sytnik 1979).
Unfortunately, the majority of the studied nature reserves are polluted by ALAN and for some NNPs, such as DnieperOril, which are situated near large cities and industrial complexes, the situation will be difficult to change. For other reserves it is hoped that light pollution can be reduced as a result of collaboration and educational work with local communities.

The NNPs, Biosphere and Nature Reserves of the Steppe Zone and Crimean Mountains would be ideal locations for future investigations to study the influence of ALAN on biodiversity and ecosystems, particularly as some of the protected areas represent refugia where there is currently an unpolluted natural night sky. Protected areas within the Steppe Zone and Crimean Mountains already play a key role in the study of biodiversity and habitat conservation within the Emerald Network (Polyanska et al. 2017). It is recommended that the majority of NNPs, Biosphere and Nature Reserves of the Steppe Zone and Crimean Mountains participate in the International Dark Sky Places conservation program (http://darksky.org/idsp/) which has been initiated by the International Dark-Sky Association since 2001 (Barentine 2016). Fulfilling the requirements for International Dark Sky Places should provide benefits for both biodiversity conservation and tourism within protected areas.

\section{Author contributions}

The investigation was planned and conducted by M.P. and E.P.K. M.P. and O.V. prepared maps and figures for the 
Table 1. Areas with different levels of artificial sky brightness in the National Nature Parks, Biosphere and Nature Reserves of the Steppe Zone and Crimean Mountains in Ukraine.

\section{Protected area}

Square of areas with different level of artificial brightness $\left(\mathrm{mcd} / \mathrm{m}^{2}\right), \mathrm{km}^{2}$

\begin{tabular}{|c|c|c|c|c|c|c|c|c|c|c|c|c|c|c|}
\hline & $<1.74$ & $\begin{array}{c}1.74- \\
3.48\end{array}$ & $\begin{array}{c}>3.48- \\
6.96\end{array}$ & $\begin{array}{c}>6.96- \\
13.9\end{array}$ & $\begin{array}{c}>13.9- \\
27.8\end{array}$ & $\begin{array}{c}>27.8- \\
55.7\end{array}$ & $\begin{array}{c}>55.7- \\
111\end{array}$ & $\begin{array}{c}>111- \\
223\end{array}$ & $\begin{array}{c}>223- \\
445\end{array}$ & $\begin{array}{c}>445- \\
890\end{array}$ & $>890$ & & \\
\hline \multicolumn{2}{|c|}{ Azov-Syvash NNP } & 213.1 & 244.7 & 42.5 & 7.2 & 4.3 & - & - & - & - & - & - & 511.8 & 521.5 \\
\hline \multicolumn{2}{|c|}{ Dvorichna NNP } & - & - & - & 23.9 & 9.1 & 1.2 & - & - & - & - & - & 34.2 & 31.3 \\
\hline \multicolumn{2}{|c|}{ Dzharylgach NNP } & - & 1.0 & 50.5 & 46.2 & 1.7 & 6.8 & 3.4 & 0.9 & 0.2 & - & - & 110.7 & 100.0 \\
\hline \multicolumn{2}{|c|}{ Nyzhniodniprovsky NNP } & - & - & 11.9 & 223.1 & 242.8 & 111.2 & 86.8 & 106.5 & 50.5 & 3.9 & - & 836.7 & 801.8 \\
\hline \multicolumn{2}{|c|}{ Nyzhniodnistrovsky NNP } & - & - & - & - & - & 99.1 & 97.4 & 18.6 & - & - & - & 215.1 & 213.1 \\
\hline \multicolumn{2}{|c|}{$\begin{array}{l}\text { NNP “Biloberezhzhia Svia- } \\
\text { toslava” }\end{array}$} & - & - & 50.9 & 205.6 & 81.2 & 11.4 & 0.9 & - & - & - & - & 350.0 & 352.2 \\
\hline \multicolumn{2}{|c|}{ NNP “Buz'kyi Gard” } & - & - & - & 3.6 & 15.1 & 25.9 & 9.8 & 2.0 & 4.6 & 0.3 & & 61.3 & 61.4 \\
\hline \multicolumn{2}{|c|}{ NNP “Charivna Havan”” } & - & 2.7 & 56.0 & 32.8 & 14.3 & 1.5 & - & - & -- & - & - & 107.3 & 109.0 \\
\hline \multicolumn{2}{|c|}{ NNP “Homilshanski Forests” } & - & - & - & - & 22.3 & 79.9 & 39.9 & - & - & - & - & 142.1 & 143.2 \\
\hline \multicolumn{2}{|c|}{ NNP “Meotyda” } & - & - & - & 16.7 & 55.5 & 89.0 & 47.3 & 10.8 & 1.1 & 0.2 & - & 220.6 & 207.2 \\
\hline \multicolumn{2}{|c|}{ NNP “Oleshky Sands” } & - & - & - & 53.5 & 27.1 & - & - & - & - & - & - & 80.6 & 80.2 \\
\hline \multicolumn{2}{|c|}{ NNP "Svyati Hory" } & - & - & - & - & 61.1 & 112.7 & 166.9 & 77.0 & 8.6 & 4.4 & - & 430.7 & 406.1 \\
\hline \multicolumn{2}{|c|}{ NNP “Tuzlovs'ki Lymany” } & - & 191.8 & 67.5 & 11.3 & 1.6 & - & - & - & - & - & - & 272.2 & 278.7 \\
\hline \multicolumn{2}{|c|}{ NNP “Velykyi Luh” } & - & - & - & - & 108.6 & 52.6 & 0.5 & 1.9 & 2.1 & - & - & 165.7 & 167.6 \\
\hline \multicolumn{2}{|c|}{ Pryazovsky NPP } & - & 58.8 & 239.9 & 120.2 & 137.0 & 96.2 & 90.7 & 25.5 & 0.8 & - & - & 769.1 & 781.3 \\
\hline \multicolumn{2}{|c|}{$\begin{array}{l}\text { Askania-Nova Biosphere Re- } \\
\text { serve }\end{array}$} & - & 194.1 & 117.7 & 13.8 & 5.8 & - & - & - & - & - & - & 331.4 & 333.1 \\
\hline \multicolumn{2}{|c|}{ Black Sea Biosphere Reserve } & - & 516.3 & 608.0 & 24.3 & 6.8 & - & - & - & - & - & - & $1,155.4$ & $1,092.6$ \\
\hline \multicolumn{2}{|c|}{ Danubian Biosphere Reserve } & 14.3 & 206.6 & 117.1 & 133.0 & 25.1 & 3.8 & - & - & - & - & - & 499.9 & 502.5 \\
\hline \multicolumn{2}{|c|}{ Cape Martian Nature Reserve } & - & - & - & - & - & - & - & - & 2.4 & - & - & 2.4 & 2.4 \\
\hline \multirow{2}{*}{$\begin{array}{l}\text { Crimea } \\
\text { Nature } \\
\text { Reserve }\end{array}$} & - Mountain part & - & - & - & - & 156.1 & 120.5 & 37.2 & 29.2 & 0.3 & 0.7 & - & 344.0 & 345.6 \\
\hline & - Swan islands part & - & 20.4 & 59.1 & 18.3 & - & - & - & - & - & - & - & 97.8 & 96.1 \\
\hline \multicolumn{2}{|c|}{ Dnieper-Oril Nature Reserve } & - & - & - & - & - & - & - & - & 33.5 & 4.0 & - & 37.5 & 37.7 \\
\hline \multicolumn{2}{|c|}{ Karadag Nature Reserve } & - & - & - & - & 19.9 & 4.0 & 4.4 & - & - & - & - & 28.3 & 28.7 \\
\hline \multicolumn{2}{|c|}{ Kazantyp Nature Reserve } & - & - & - & 0.3 & 2.3 & 1.9 & - & - & - & - & - & 4.5 & 4.5 \\
\hline & $\begin{array}{l}\text {-"Provalsky } \\
\text { Steppe" }\end{array}$ & - & - & - & - & - & - & 5.9 & - & - & - & - & 5.9 & 5.9 \\
\hline $\begin{array}{l}\text { Lugansk } \\
\text { Nature } \\
\text { Reserve }\end{array}$ & $\begin{array}{l}\text {-"Stanychno- } \\
\text { Luganske" }\end{array}$ & - & - & - & - & - & 4.9 & - & - & - & - & - & 4.9 & 5.0 \\
\hline & $\begin{array}{l}\text {-"Striltsivsky } \\
\text { Steppe" }\end{array}$ & - & - & - & 0.5 & 10.1 & - & - & - & - & - & - & 10.6 & 10.4 \\
\hline $\begin{array}{l}\text { Nature Re } \\
\text { Steppe" }\end{array}$ & erve "Yelanets & - & - & 16.7 & - & - & - & - & - & - & - & - & 16.7 & 16.8 \\
\hline Opuk Natı & re Reserve & - & - & 15.6 & 0.4 & - & - & - & - & - & - & - & 16.0 & 15.9 \\
\hline Ukrainian & $\begin{array}{l}\text { "Khomutovsky } \\
\text { Steppe" }\end{array}$ & - & - & - & - & 10.2 & - & - & - & - & - & - & 10.2 & 10.3 \\
\hline $\begin{array}{l}\text { Steppe } \\
\text { Nature }\end{array}$ & “Kamyani Mohyly" & - & - & - & - & 4.1 & - & - & - & - & - & - & 4.1 & 4.0 \\
\hline Reserve & "Kreidova Flora" & - & - & - & - & - & 8.3 & 3.3 & - & - & - & - & 11.6 & 11.3 \\
\hline & "Kal'mius'ke" & - & - & - & - & 5.4 & 2.2 & - & - & - & - & - & 7.6 & 5.8 \\
\hline $\begin{array}{l}\text { Yalta Mou } \\
\text { Reserve }\end{array}$ & tain-Forest Nature & - & - & - & - & - & 30.6 & 31.9 & 14.2 & 63.0 & 7.5 & - & 147.2 & 145.2 \\
\hline & & 227.4 & $1,436.4$ & $1,453.4$ & 934.7 & $1,027.5$ & 863.7 & 626.3 & 286.6 & 167.1 & 21.0 & 0 & $7,044.1$ & \\
\hline & & $3.2 \%$ & $20.4 \%$ & $20.6 \%$ & $13.2 \%$ & $14.6 \%$ & $12.3 \%$ & $8.9 \%$ & $4.1 \%$ & $2.4 \%$ & $0.3 \%$ & 0 & $100 \%$ & \\
\hline
\end{tabular}

Calcu- Offi-

lated cial

area, area,

$\mathrm{km}^{2} \quad \mathrm{~km}^{2}$ 
publication. M.P. drafted the manuscript while all other authors checked, improved and approved it.

\section{Acknowledgements}

The research has been carried out within the framework of the project EFOP-3.6.2-16-2017-00014 " Development of an international research environment in the field of light pollution testing ". Authors are very grateful to a team of researchers led by Fabio Falchi who provided the kmz-layer "The New World Atlas of Artificial Sky Brightness" prepared as a result of their project (https://cires.colorado.edu/ Artificial-light), as well to Mariia Savchenko (Taras Shevchenko National University of Kyiv) who helped with the preparation of maps and figures. Also thanks to Peter Török for editorial handling and Jim Martin for linguistic editing.

\section{References}

Barentine, J. 2016. Going for the Gold: quantifying and ranking visual night sky quality in International Dark Sky Places. International Journal of Sustainable Lighting 35: 9-15.

Beier, P. 2006. Effects of artificial night lighting on terrestrial mammals. In: Rich, C. \& Longcore, T. (eds.) Ecological consequences of artificial night lighting, pp. 15-42. Island Press, Washington, DC, US.

Bennie, J., Davies, T.W., Duffy, J.P., Inger, R. \& Gaston, K.J. 2014. Contrasting trends in light pollution across Europe based on satellite observed night time lights. Scientific Reports 4: Article 3789.

Bennie, J., Davies, T.W., Cruse, D., Inger, R. \& Gaston, K.J. 2015a. Cascading effects of artificial light at night: resource-mediated control of herbivores in a grassland ecosystem. Philosophical Transactions of the Royal Society B 370: Article 20140131.

Bennie, J., Duffy, J.P., Davies, Y.W., Correa-Cano, M.E. \& Gaston, K.J. 2015b. Global trends in exposure to light pollution in natural terrestrial ecosystems. Remote Sensing 7: 2715-2730.

Bennie, J., Davies, T.W., Cruse, D. \& Gaston, K.J. 2016. Ecological effects of artificial light at night on wild plants. Journal of Ecology 104: 611-620.

Bennie, J., Davies, T.W., Cruse, D., Bell, F. \& Gaston, K.J. 2018. Artificial light at night alters grassland vegetation species composition and phenology. Journal of Applied Ecology 55: 442-450.

Briggs, W.R. 2006. Physiology of plant responses to artificial lighting. In: Rich, C. \& Longcore, T. (eds.) Ecological consequences of artificial night lighting, pp. 389-412. Island Press, Washington, DC, US.

Burkovskyi, O.P., Vasyliuk, O.V., Yena, A.V., Kuzemko, A.A., Movchan, Y.I., Moysiyenko, I.I. \& Sirenko, I.P. 2013. Ostanni stepy Ukrainy: buty chy ne buty? [The last steppes of Ukraine: to be or not to be?]. Geoprynt, Kyiv, UA. [In Ukrainian]

Dengler, J., Janisová, M., Török, P. \& Wellstein, C. 2014. Biodiversity of Palaearctic grasslands: a synthesis. Agriculture, Ecosystems \& Environment 182: 1-14.

Didukh, Y.P. \& Shelyah-Sosonko, Y.R. 2003. Heobotanichne raionuvannya Ukrainy ta sumizhnykh terytoriy [Geobotanical zoning of Ukraine and adjacent territories]. Ukrains'kyi Botanichnyi Zhurnal, 60 (1): 6-11. [In Ukrainian]

Falchi, F., Cinzano, P., Duriscoe, D., Kyba, C.C.M., Elvidge, C.D., Baugh, K., Portnov, B.A., Rybnikova, N.A. \& Furgoni, R. 2016. The new world atlas of artificial night sky brightness. Science Advances 2: Article e1600377.
Frank, K.D. 2006. Effects of artificial night lighting on moths. In: Rich, C. \& Longcore, T. (eds.) Ecological consequences of artificial night lighting, pp. 389-412. Island Press, Washington, DC, US.

Gaston, K.J. \& Bennie, J. 2014. Demographic effects of artificial nighttime lighting on animal populations. Environmental Reviews 22: 323-330.

Gaston, K.J., Bennie, J., Davies, T.W. \& Hopkins, J. 2013. The ecological impacts of nighttime light pollution: a mechanistic appraisal. Biological Reviews 88: 912-927.

Gaston, K.J., Gaston, S., Bennie, J. \& Hopkins, J. 2014. Benefits and costs of artificial nighttime lighting of the environment. Environmental Reviews 23: 14-23.

Gaston, K.J., Duffy, J.P. \& Bennie, J. 2015. Quantifying the erosion of natural darkness in the global protected area system. Conservation Biology 29: 1132-1141.

van Geffen, K.G., van Grunsven, R.H.A., van Ruijven, J., Berendse, F. \& Veenendaal, E.M. 2014. Artificial light at night causes diapause inhibition and sex-specific life history changes in a moth. Ecology and Evolution 4: 2082-2089.

van Geffen, K.G., van Eck, E., de Boer, R.A., van Grunsven, R.H.A., Salis, L., Berendse, F. \& Veenendaal, E.M. 2015. Artificial light at night inhibits mating in a Geometrid moth. Insect Conservation and Diversity 8: 282-287.

Grubisic, M., van Grunsven, R. H. A., Kyba, C. C. M., Manfrin, A. \& Hölker, F. 2018. Insect declines and agroecosystems: does light pollution matter? Annals of Applied Biology 173: 180189.

Hallmann, C.A., Sorg, M., Jongejans, E., Siepel, H., Hofland, N., Schwan, H., Stenmans, W., Müller, A., Sumser, H., (...) \& De Kroon, H. 2017. More than 75 percent decline over 27 years in total flying insect biomass in protected areas. PLOS ONE 12: Article e0185809.

Hölker, F., Wolter, C., Perkin, E. K. \& Tockner, K. 2010. Light pollution as a biodiversity threat. Trends in Ecology \& Evolution 25: 681-682.

Knop, E., Zoller, L., Ryser, R., Gerpe, Ch., Hörler, M. \& Fontaine, C. 2017. Artificial light at night as a new threat to pollination. Nature 548: 206-209.

Kolomytsev, G. \& Vasyliuk, O. 2013. Prostorovyi rozpodil stepovykh ecosystem skhodu Ukrainy [Spatial distribution of steppe ecosystems in the Eastern Ukraine]. Proceedings of the National Museum of Natural History 11: 87-92. [In Ukrainian]

Korotchenko, I.A. \& Peregrym, M.M. 2012. Ukrainian steppes in the past, at present and in the future. In: Werger, M.J.A. \& van Staalduinen, M.A. (eds.) Eurasian steppes. ecological problems and livelihoods in a changing world, pp. 173-196. Springer, Dordrecht, NL.

Krivohizha, M.V., Vasyliuk, O.V., Kolomytsev, G.O. \& Balashov, I.O. 2014. Poshyrennya ta problem okhorony vykhodiv kreidyanykh pored I kharakternykh dlya nykh ridkisnykh vydiv Roslyn na terytorii Lugans'koi oblasti [Distribution and conservation problems of the chalky outcrops and their characteristic rare plants species in Lugansk region]. Herald of the Taras Schevchenko National University of Kyiv, Series Introduction and Conservation of Plant Diversity 20(1): 32-38. [In Ukrainian]

Kurvers, R.H.J.M. \& Hölker, F. 2015. Bright nights and social interactions: a neglected issue. Behavioral Ecology 26: 334-339.

van Langevelde, F., Ettema, J.A., Donners, M., WallisDeVries, M.F. \& Groenendijk, D. 2011. Effect of spectral composition of artificial light on the attraction of moths. Biological Conservation 144: 2274-2281.

Longcore, T. \& Rich, C. 2004. Ecological light pollution. Frontiers in Ecology and the Environment 2: 191-198. 
Macgregor, C.J., Pocock, M.J.O., Fox, R. \& Evans, D.M. 2015. Pollination by nocturnal Lepidoptera, and the effects of light pollution: a review. Ecological Entomology 40: 187-198.

Mala, Y.I. 2016. Mezha mizh Lisostepom I Stepom: ekolohotsenotychna otsinka [The border between forest-steppe and steppe: ecological-cenototic evaluation]. Naukova Dumka, Kyiv, UA. [In Ukrainian]

Matzke, E.B. 1936. The effect of street lights in delaying leaf-fall in certain trees. American Journal of Botany 23: 446-452.

McColgan, M.W. 2003. Light Pollution. Lighting Answers 7(2): 216.

Navara, K.J. \& Nelson, R.J. 2012. The dark side of light at night: physiological, epidemiological, and ecological consequences. Journal of Pineal Research 43: 215-224.

Polyanska, K.V., Borysenko, K.A., Pawlaczyk, P., Vasyliuk, O.V., Maruschak, O.Y., Shyriaieva, D.V., Kuzemko, A.A., Oskyrko O.S., Nekrasova, O.D., (...) \& Bezsmertna, O.O. 2017. Zaluchennya hromadskosti ta naukovtsiv do proektuvannya merezhi Emerald (Smaragdovoi merezhi) $v$ Ukraini [Involvement of the public and scientists to the design of the Emerald network in Ukraine]. Kyiv, UA. [In Ukrainian]

Rotics, S., Dayan, T. \& Kronfeld-Schor, N. 2011. Effect of artificial night lighting on temporally partitioned spiny mice. Journal of Mammalogy 92: 159-168.

Sanders, D., Kehoe, R., Tiley, K., Bennie, J., Cruse, D., Davies, T.W., van Veen, F.F.J. \& Gaston, K.J. 2015. Artificial nighttime light changes aphid-parasitoid population dynamics. Scientific Reports 5: Article 15232.

Schroeder, C.A. 1945. Tree foliation affected by street lights. Arborists News 10: 1-3.

Shyriaieva, D., Vasyliuk, O. \& Kolomytsev, G. 2014a. Prostorovyi rozpodil stepovykh biotopiv Odes'koi oblasti $v$ konteksti heobotanichnoho raionuvannya terytorii [Spatial distribution of steppe biotops of Odesa region in the context of geobotanical zoning]. Materialy Mizhnarodnoi naukovopraktychnoi konferencii "Teoretychni ta prykladni aspekty rozvytku pryrodnychykh dystsyplin" (Poltava, November, 2021, 2014). Drukars'ka maisternya. pp. 115-118. Poltava, UA. [In Ukrainian]
Shyriaieva, D., Vasyliuk, O. \& Kolomytsev, G. 2014b. Rozpodil stepovykh biotopiv Khersons'koi oblasti zhidno heobotanichnoho raionuvannya [Distribution of steppe biotops of Kherson region according to geobotanical zoning]. Materialy Mizhnarodnoi naukovo-praktychnoi konferencii molodykh uchenykh, studentiv, aspirantiv "Ekolohizatsiya staloho rozvytku informatsiinoho suspilstva" (Kharkiv, November, 5-6, 2014). pp. 315-317. KhNAU, Kharkiv, UA. [In Ukrainian]

Sytnik, K.M. (ed.) 1979. Okhrana vazhneishykn botanicheskikh ob'ektov Ukrainy, Belorussii, Moldavii [Conservation of the most important botanical objects of Ukraine, Belorussia, Moldavia]. Naukova Dumka, Kiev, UA. [In Russian]

Török, P. \& Dengler, J. 2018. Palaearctic grasslands in transition: overarching patterns and future prospects. In: Squires, V.R., Dengler, J., Feng, H. \& Hua, L. (eds.) Grasslands of the world: diversity, management and conservation, pp. 15-26. CRC Press, Boca Raton, US.

Török, P. Janišová, M., Kuzemko, A., Rūsiṇa, S. \& Dajic-Stevanovic, Z. 2018. Grasslands, their threats and management in Eastern Europe. In: Squires, V.R., Dengler, J., Feng, H. \& Hua, L. (eds.) Grasslands of the world: diversity, management and conservation, pp. 64-88. CRC Press, Boca Raton, US.

Vasyliuk, O., Balashov, I., Krivohizha, M. \& Kolomytsev, G. 2012. Landshaftnyi sklad pryrodno-zapovidnoho fondu Lugans'koi oblasti [Landscape structure of the nature reserve fund of Lugansk region]. Nature Reserves in Ukraine 18(1-2): 105110. [In Ukrainian]

Vasyliuk, O., Kolomytsev, G. \& Shyriaieva, D. 2014. Inventarizatsiya melovykh stepei v Ukraine. Soobshenie 2: Kharkovskaya i Donetskaya oblasti [Inventory of chalky steppes in Ukraine. Report 2: Kharkiv and Donetsk regions]. Steppe Bulletin 41: 26 -29. [In Russian]

Wesche, K., Ambarli, D., Kamp, J., Török, P., Treiber, J. \& Dengler, J. 2016. The Palaearctic steppe biome: a new synthesis. Biodiversity and Conservation 25: 2197-2231. 


\section{Steppe reserves of Ukraine $\mathbf{- ~} \mathbf{9 0}$ years}

The very first and most important of the Ukrainian protected areas (PA) belonged to the National Sciences Academy of Ukraine. From the first years of operation, the reserves created by botanists and zoologists were functioning as biological stations for studying ecosystems and biodiversity. This informed the traditional perception of the reserves as scientific institutions. Today they are the classical domain of biological research and carry out work on long-term monitoring of environmental change (Akimov \& Kotenko 2005).

The current publication includes a review of historical information on the nature reserves of the Steppe zone of Ukraine, established in 1928 and forming the core of the natural reserves network of the National Sciences Academy of Ukraine. They all celebrate their 90th anniversary, having developed in different ways and currently being in different, but difficult situation.

\section{"Kreidova flora" Reserve}

The reserve is located on the steep right bank of the Seversky Donets River. It is probably the only place in the country demonstrating vegetation in a satisfactory state of conservation on soils formed on chalk rocks. Forests occupy about a third of the territory of the reserve and are equally represented by pine and oak forests on chalk deposites. In total 490 species of vascular plants grow here. Cretaceous flora is the only site in the Ukraine where natural chalky pine woods are protected.

"Cretaceous pine wood near Lavrentievka village", within the boundaries of Artemovsk city council, was declared a natural monument for the first time in 1928.

The history of the reserve began in 1927. As E. Lavrenko mentioned in the publication of 1928 , according to a post-

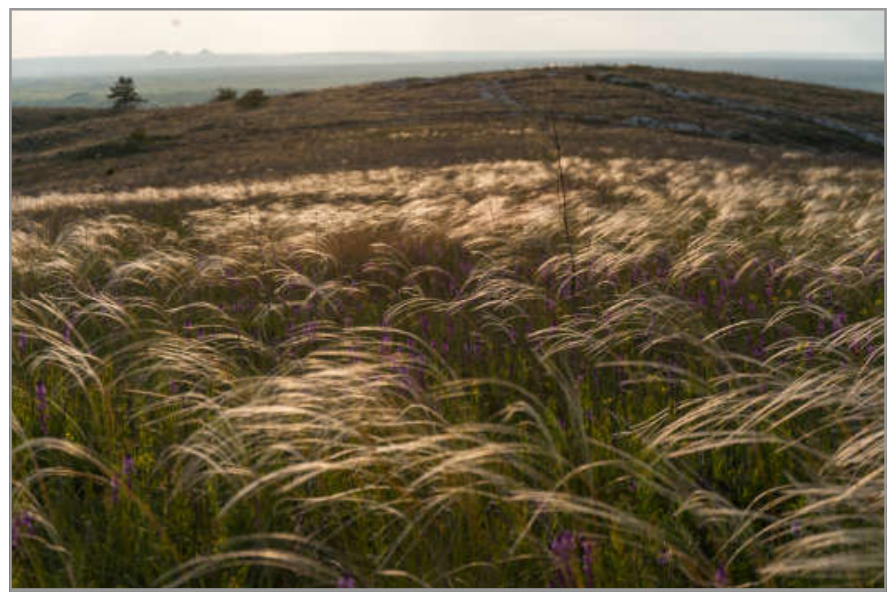

"Kreidova flora" Reserve, feather grass. Photo: D. Balkhovitin. graduate student of the Department of General Forestry, V. Akopov, "the latter managed to find 3-4 sections of small natural plantations of pine near the village of Lavrentyevka, by Krivaya Luka village, on the chalk outcrops of the right bank of the Donets valley. According to the information received from the local population, these chalky pine woods are natural. In these plantings a natural regeneration of the pine is observed" (Lavrenko 1928).

The precise date of the monument's announcement is unknown. In 1932 the natural monument had a republican significance. At the beginning of 1929, in the letter of the E. Lavrenko to the Artemovsky District Executive Committee, measures were recommended for the protection of the monument, namely: "it requires protection, no cut down, and no grazing," "studying such a pine woods is of great importance from the point of view of reclamation, planting pine chalk outcrops ".

In the post-war period, the conservation status of the monument was only restored in 1988, when the decree of the Council of Ministers of the Ukrainian SSR №310-P of 14.07.1988 on the area of 1134.0 hectares announced the separation of the Ukrainian steppe nature reserve "Kreidova flora." In this case, it is officially considered in 2018 that the reserve is not 90 years old, but 30 .

\section{"Mikhailovskaya Tselina" Reserve}

The vegetation cover of the reserve is similar to the vegetation of the southern steppes. The dominant vegetation is composed of mixed-grassland. Motley-fescue-typhus formations mainly grow in the southeastern and eastern parts of the reserve. However, Mikhailovskaya steppe also demonstrates vegetation, typical to the northern steppes. There are few feathery feather grasses and many broad-leaved grasses and other plants not found in the steppes of the south. 493 plant species are recorded here.

It was firstly declared as a natural monument in 1928 and was called "Mikhailovsky horse farm Tselina land", "Shtepovskaya Tselina", "Kapnist's Tselina" or "Mikhailovskaya steppe." All these names refer to the territory of the same reserve which was created in 1928 within the Sumy region.

In 1928 E. Lavrenko wrote, "There are only about 215 dessiatins left; they are used for haymaking and, partially, for grazing. The state of the tselina vegetation is generally good. This tselina has an extremely high scientific value, because it is the only left in the forest-steppe zone "(Lavrenko 1927).

At the end of 1927, the Ukrainian Committee for the Protection of Nature's Monuments (UCPNM) appealed to the Sumy Oblast Executive Committee (OEC) with a request to create a state reserve "Kapnist's Tselina". The letter provided specific requirements for the regime of the future reserve: to stop ploughing tselina land; not to carry out excessive grazing and other measures negatively affecting 
the conservation of tselina vegetation. In future tselina can be used for haymaking (Lavrenko 1927).

The mandatory resolution of the Sumy OEC "On declaring the Mikhailovskaya Tselina land as a nature reserve" was adopted on July 13, 1928. According to it, a natural reserve was created on the area of 178 hectares, on the territory of which "grazing, fertilizing, sowing any plants, stacking of haystacks, as well as access of horses during haymaking, except for hay necessary for laying new ways, is forbidden. Mikhailovsky stud farm, for the use of which the Tselina soil bursts, has the right in the western part of the massif, at the factory farm, to use 65 desyatinas for grazing of pedigree horses."

Part 3 of the decree states that "on all Tselina lands and in its immediate vicinity with a radius of $1 \mathrm{~km}$ from the Tselina land, hunting and bonfire are definitely forbidden". Compliance with this regime is assigned to the stud farm and the control - to the ordnance department.

From 1929 information about the reserve was included in the card file of the Central Bureau of Regional Studies (Leningrad). It was believed that Mikhailovskaya Tselina land is of great importance for studying the natural resources of the forest-steppe of Ukraine. In 1932, the UCPNM planned to declare the monument a state reserve in the Second Five-Year Plan.

February 23, 1937 Kharkov OEC issued a new resolution which declared Mikhailovskaya Tselina land a reserve of local significance (Kotov 1937). At that time the territory was used by the Vasilievsky collective farm for grazing and haymaking. On March 27, 1948, the Council of Ministers of the Ukrainian SSR issued Decree No. 444 "On the Announcement of the Streletsky Steppe" in the Melovsky District of the Voroshilovgrad Region and the "Mikhailovskaya Tselina" in the Shtepovsky District of the Sumy Region, in which Mikhailovskaya Tselina land was declared a State Reserve on an area of 202 hectares. Resolution establishes a kilometer buffer zone around the reserve.

In 1961 the reserve "Mikhailovskaya Tselina" became part of the Ukrainian State Steppe Reserve and the research base of the Institute of Botany of the Academy of Sciences of the Ukrainian SSR.

Thanks to the institutional linkage of the steppe reserves with the National Academy of Sciences of Ukraine, longterm studies of environmental change, monitoring of biodiversity and ecosystem dynamics are conducted throughout their range. Steppe reserves of the National Academy of Sciences of Ukraine (NAS of Ukraine) are absolute record holders, among the nature protection territories of Ukraine, in terms of the number of scientific and popular scientific publications about them. At the same time, these reserves remain relatively small and, as a rule, are the last remaining representatives of these types of biotopes and landscapes preserved in their natural state. Reserves of the NAS of Ukraine has a small area, but that are most representatively cover all the main types of vegetation in the Steppe zone of Ukraine.

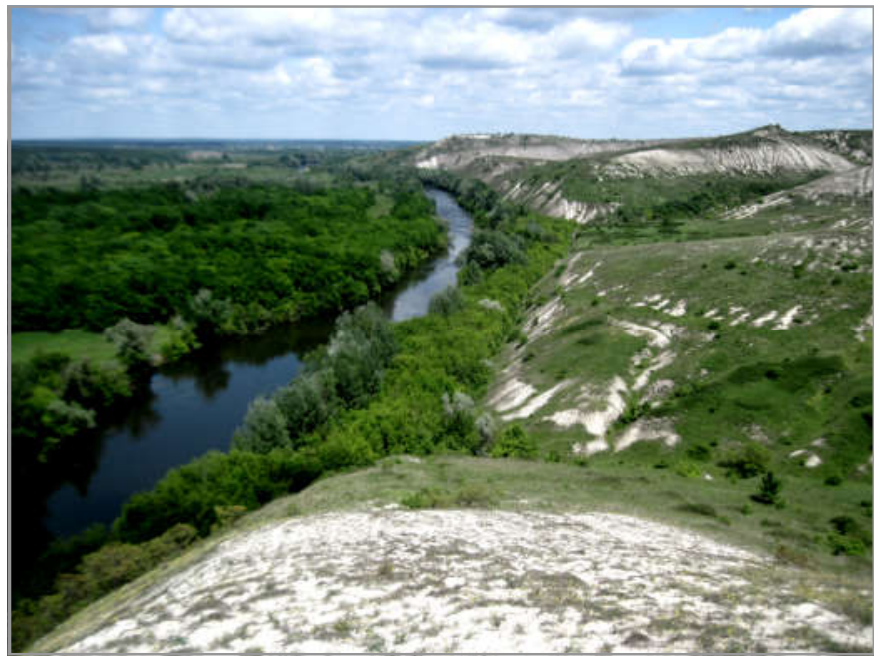

Siversky Donets flows along the boundary of "Kreidova flora". Photo: S. Lymanskyy.

The question of the future of the steppe reserves remains unclear. As island ecosystems, protected in reserves over the past 90 years from the direct impact of agriculture and other disastrous anthropogenic factors, are now surrounded by previously imperceptible environmental problems. During the 90-year period since the establishment of the reserves significant changes in environment and agriculture have occurred: the climate have changed, lots of introduced plant species have appeared. Moreover, most of the steppes surrounding the reserves were transformed into agricultural fields. Therefore, since their establishment the reserves have become the "biodiversity islands", surrounded by multiple negative factors. The rapid reserve succession caused by the conservation regime and influenced by climate change make the future of the reserves increasingly vague.

The actual issue at present is no longer the maintenance of a strict regime of non-interference in natural processes, but, on the contrary, the development of emergency scientifically grounded measures to protect the reserves' ecosystems from the harmful effects of environmental factors that directly or indirectly emanate from the effects of anthropogenic activities.

Credits to Maksym Kuzhdin, Yehor Hrynyk.

\section{References}

Akimov, I.A. \& Kotenko T.I. 2005. O nauchno-issledovatel'skoj rabote v zapovednikah, podchinennyh Nacional'noj akademii nauk Ukrainy [About research work in the reserves, subordinate to the National Academy of Sciences of Ukraine]. Istoriya zapovednogo dela: Materialy mezhdunar. nauch. konf.: 3739. [In Russian]

Lavrenko, Y.M. 1928. Nova znahidka sosni na krejdi ponad r. Doncem [A new find of Pine Creek over the Don River]. Ohorona pam'yatok prirodi na Ukraïni 2: 114. [In Ukrainian]

Lavrenko, Y.M. 1927. Ohorona prirodi na Ukraïni [Nature conservation in Ukraine]. Visnik prirodoznavstva 3-4: 165. [In Ukrainian]

Kotov, M.I. 1937. Novye zapovedniki na Ukraine [New nature reserves in Ukraine]. Priroda 8: 105-109. [In Russian] 


\title{
Dry grassland on ancient burial mounds - kurgans of the Carpathian basin
}

\author{
Photos and text by Balázs Deák
}

MTA DE Biodiversity and Ecosystems Research Group, Egyetem tér 1, H4032, Debrecen, Hungary; e-mail: debalazs@gmail.com

The ancient burial mounds, so called 'kurgans', have been iconic landscape elements of the Eurasian steppe and forest steppe biomes for several millennia. Most of the kurgans were built during the Neolithic and the Iron age by steppic cultures such as the Yamnaya culture (3300-2600 BC), Scythians (900-100 BC) and Sarmatians (600 BC-400 AD). Even though many kurgans disappeared due to the landscape transformation activities such as agricultural intensification and the expansion of urban areas, there are still about 400,000-600,000 kurgans in Eurasia. They are located in the steppe and forest steppe biomes; their westernmost distribution range is in the alkali- and loess steppes of Hungary and their easternmost locality is in the semi-deserts of Mongolia. Kurgans are considered as 'sacred natural sites' as besides their inevitable cultural and historical importance they are also essential objects for nature conservation. In heavily transformed agricultural landscapes of Hungary and Ukraine steep slopes of the kurgans provide refuge for the last remnants of dry grasslands. In the lowlands of Hungary kurgans have an essential role in preserving loess vegetation, which were formed on fertile chernosemic soils especially adequate for agriculture. In spite of the increasing human influence in the landscape (ploughing, urbanisation, afforestation, establishment of roads and channels) kurgans still harbour a high biodiversity and many grassland specialist spe-

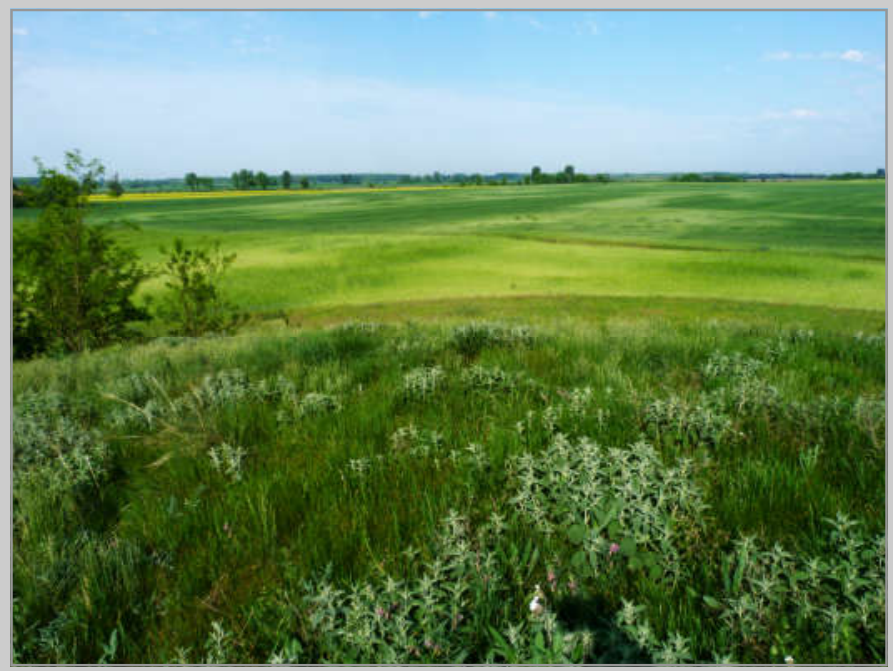

cies, thus highly contribute to the maintenance of landscapescale diversity. By preserving these historical monuments, we can also ensure the protection of endangered habitats and our cultural heritage.

Publications related to the topic:

Deák, B., Valkó, O., Török, P., Kelemen, A., Bede, Á., Csathó, A.I. \& Tóthmérész, B. 2018. Landscape and habitat and filters jointly drive richness and abundance of grassland specialist plants in terrestrial habitat islands. Landscape Ecology 33: 1117-1132.

Deák, B., Tölgyesi, C., Kelemen, A., Bátori, Z., Gallé, R., Bragina, T.M., Abil, Y.A. \& Valkó, O. 2017. Vegetation of steppic cultural heritage sites in Kazakhstan - Effects of micro-habitats and grazing intensity. Plant Ecology \& Diversity 10: 509-520.

Deák, B., Valkó, O., Török, P. \& Tóthmérész, B. 2016. Factors threatening grassland specialist plants - A multi-proxy study on the vegetation of isolated grasslands. Biological Conservation 204: 255-262.

Deák, B., Tóthmérész, B., Valkó, O., Sudnik-Wójcikowska, B., Bragina, T.-M., Moysiyenko, I., Apostolova, I., Bykov, N., Dembicz, I. \& Török, P. 2016. Cultural monuments and nature conservation: The role of kurgans in maintaining steppe vegetation. Biodiversity \& Conservation 25: 2473-2490.

For more information, visit our research blog here: https:// deakvalko.blogspot.com/, where we regularly report the new results related to the study of kurgans.

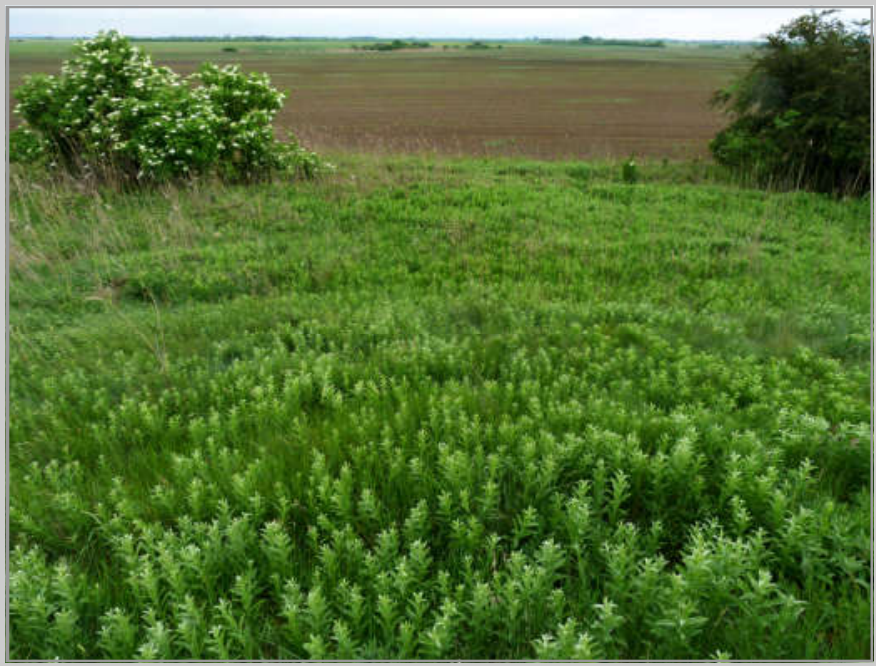




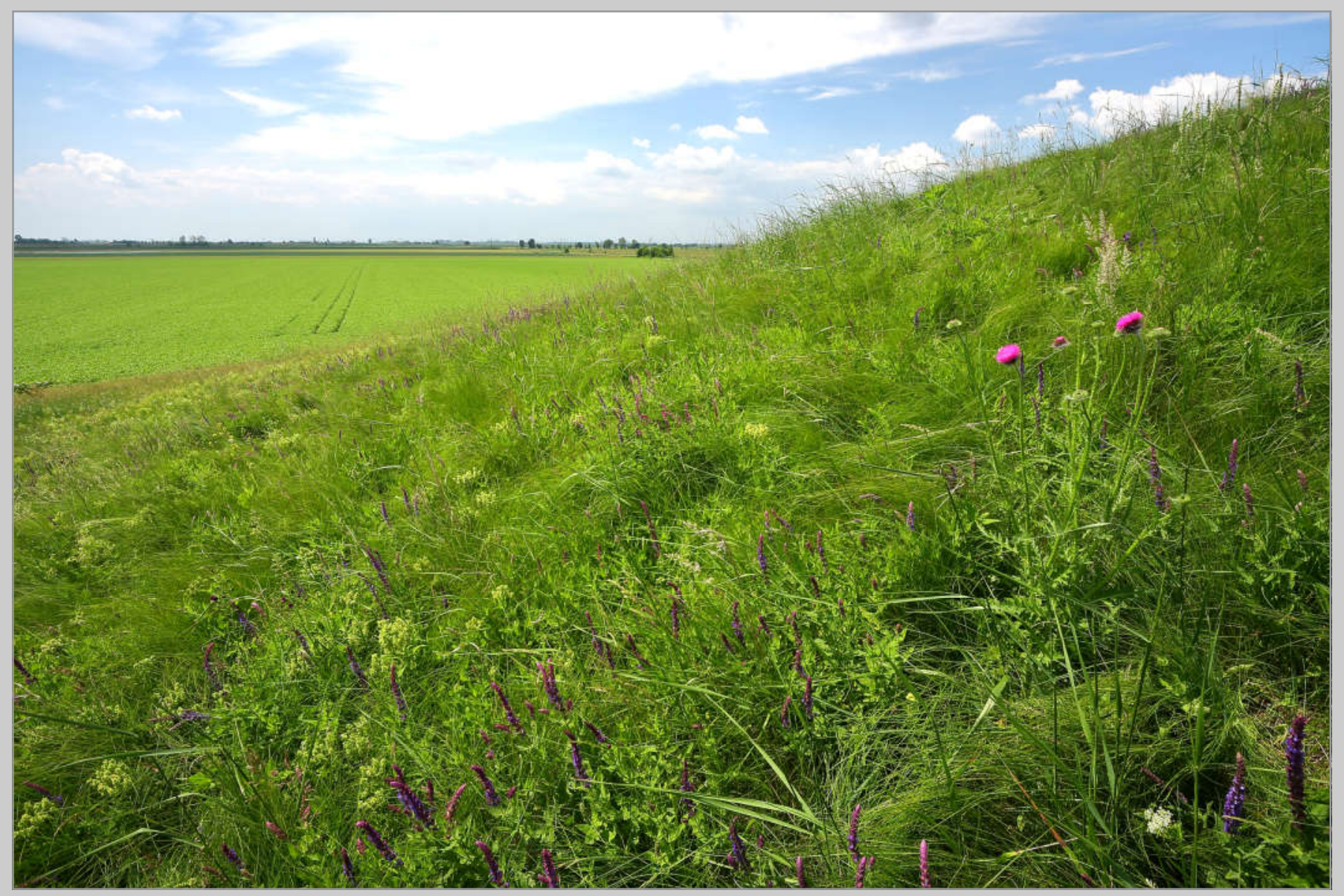

In many cases species-rich fragments of loess grasslands have been preserved on kurgans embedded in agricultural fields (top left - Szent Imre-kurgan; top right - Mondró-kurgán, bottom - Kéthalom-kurgan).
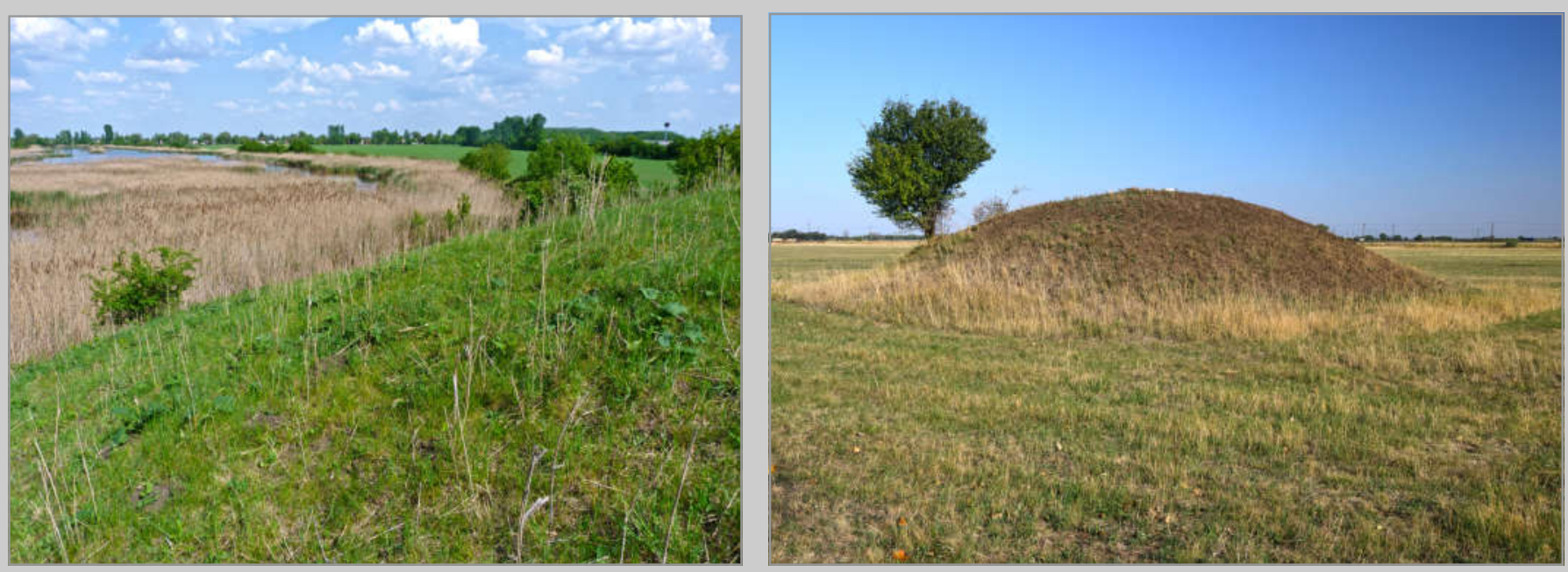

Kurgans were generally built in areas characterised by extended grasslands; however, some of them were built on riverbanks (left - Sárga-kurgan situated in the extent grasslands of the Hortobágy puszta; right - Nyéki-kurgan which was built on the bank of the Kösely-river). 

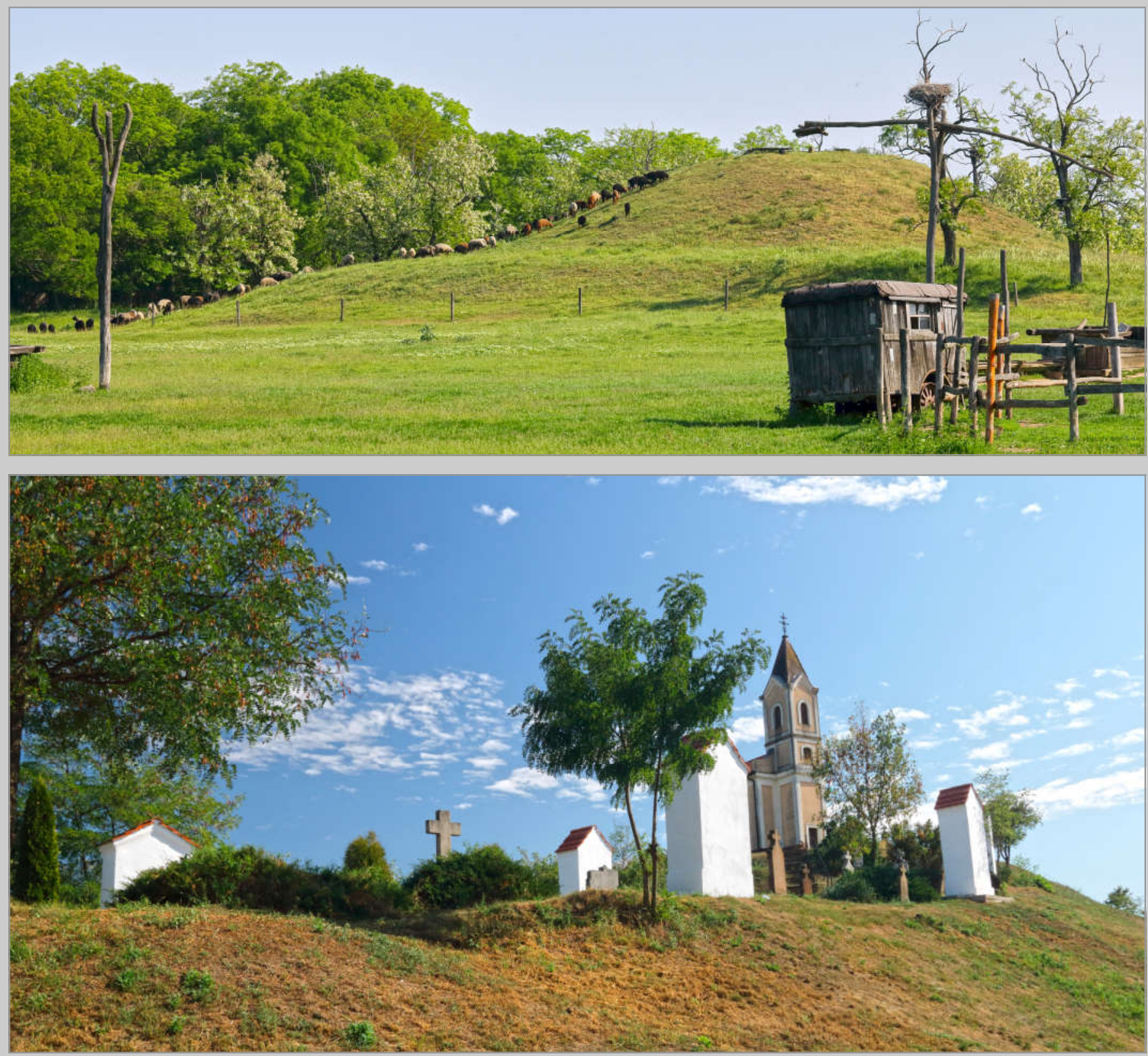

Even though kurgans were built several millennia ago, they still have an essential role in the everyday life of local people. The Filagória-kurgan (top) located in the courtyard of a farm. In many cases new cultures also used the kurgans as sacral places; a cemetery and a sanctuary on the Kálvária-kurgan (bottom).
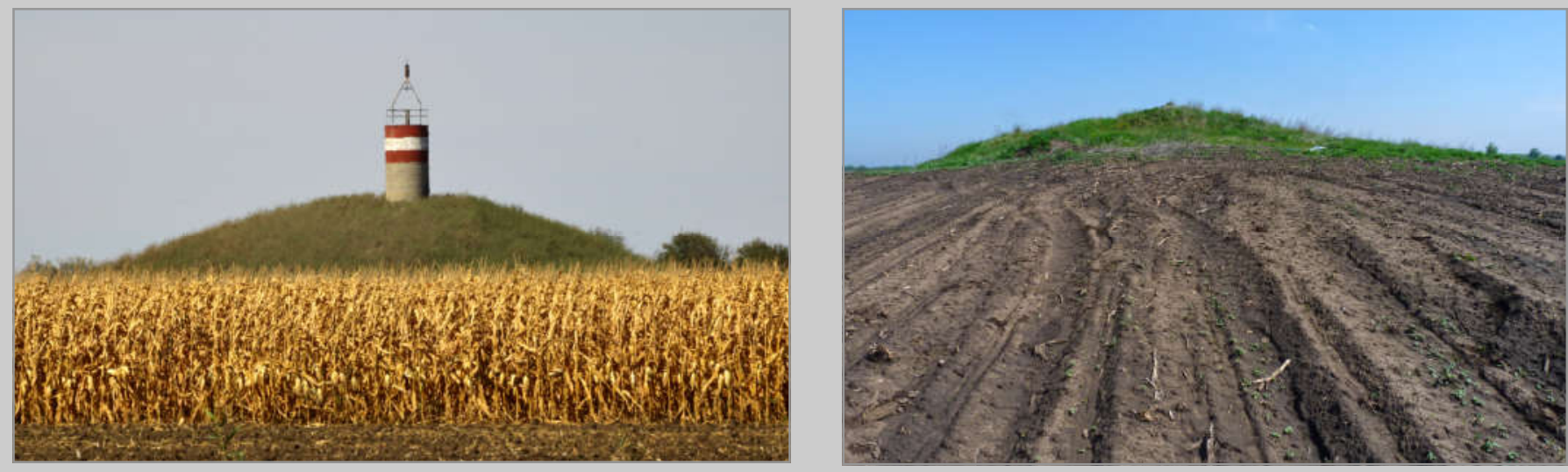

Ploughing and building are one of the major threats on the vegetation of the kurgans. A geological tower on the top of the Bürök-kurgan (left). And the almost completely ploughed Nagyhegyes-kurgan (right). 

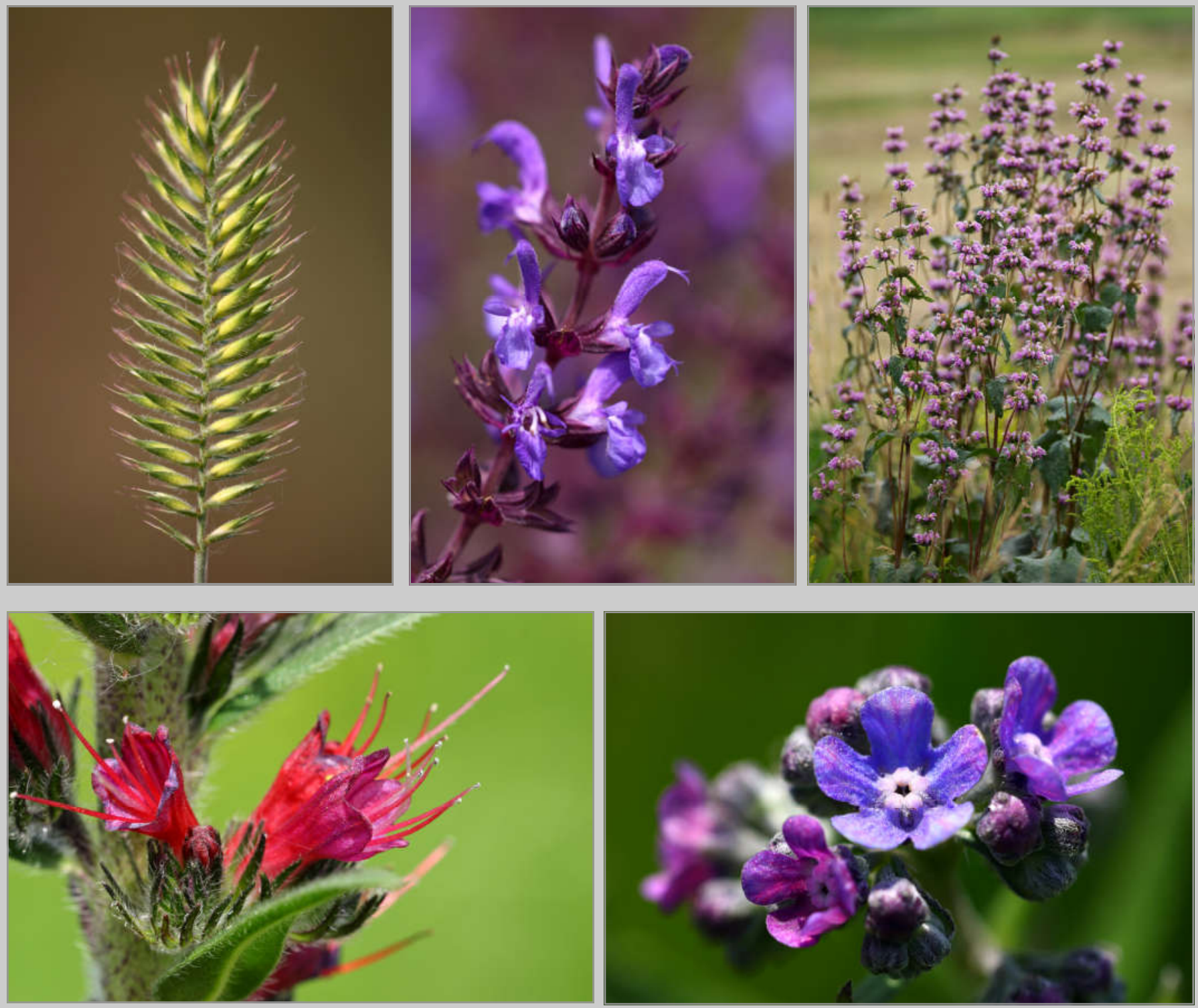

Kurgans of the Hungarian lowlands harbour many rare and protected grassland species such as the crested wheatgrass (Agropyron cristatum), woodland sage (Salvia nemorosa), tuberous Jerusalem sage (Phlomis tuberosa), red-flowered viper's grass (Echium russicum), Barrelier's bugloss (Anchusa barrelieri). 
David H. Foster: A concise guide to communication in science and engineering. Oxford University Press, Oxford, Paperback ISBN 978-0-19-87024-9 - (19.90 f)

It may be a triviality, but it is worth mentioning again and again that the findings of scientific research need to be communicated effectively. Researchers should receive credit for their research and scientific communication undoubtably facilitates career progress, whilst using various forms and media of communication helps to inform society and the wider scientific community about the research. As the saying goes "If a tree falls in a forest and no one is around to hear it, does it make a sound?" (modified after Mann \& Twiss 1910), Perhaps a new adage might be that if the results of research are not published, do they actually exist?

There are many textbooks about scientific communication (see for example a former book review by Török 2016), so what would make a researcher want to add this to their collection of reference material? The answer is quite easy and simple: because it is good. The merit of this book lies in that it tries to give real and technical help to improve the communication skills of the reader, especially in the field of technical paper drafting. The book contains thirteen chapters dealing with various aspects of scientific communication. After a short intro (Ch 1 ) the author introduces the general principles (Ch. 2) which should be kept in mind during scientific communication. Chapter 3 is one of the most important and longest chapters of the book; and it focuses on writing research papers. The book has a strong focus on writing and formal communication, and thus, informal communication i.e. posters (Ch 10) or lectures and talks (Ch 11 ) receive much less attention. Also, the preparation of literature reviews, technical reports, dissertations and theses are jointly presented in a single chapter (Ch 4). In contrast, the use of mathematics (Ch 6), data description and statistical inference (Ch 7) or graphing data (Ch 8) all receive a separate chapter. I feel that some parts of the last mentioned three chapters are either too specific (i.e. preparation of equations for the publications) or too trivial (e.g. averages or the measures of variation). However, I found chapter 5, labelled "Use of English" very useful and important, particularly for scientists and engineers for whom English is not their main language. The book introduces many important aspects which help readers to improve their scientific language and the conciseness of their manuscripts. I also found it useful that the book contains a chapter focusing on publishing of papers (e.g. journal selection and review process, Ch 9) and another dealing with ethical issues of research and publication (Ch 12).
There are two very important qualities of the book. First, at the end of each chapter there is a checklist which helps the reader summarise the key points; for example, in the chapter on Research Articles, the practical checklist focuses on the most important aspects to be considered during the drafting of specific sections

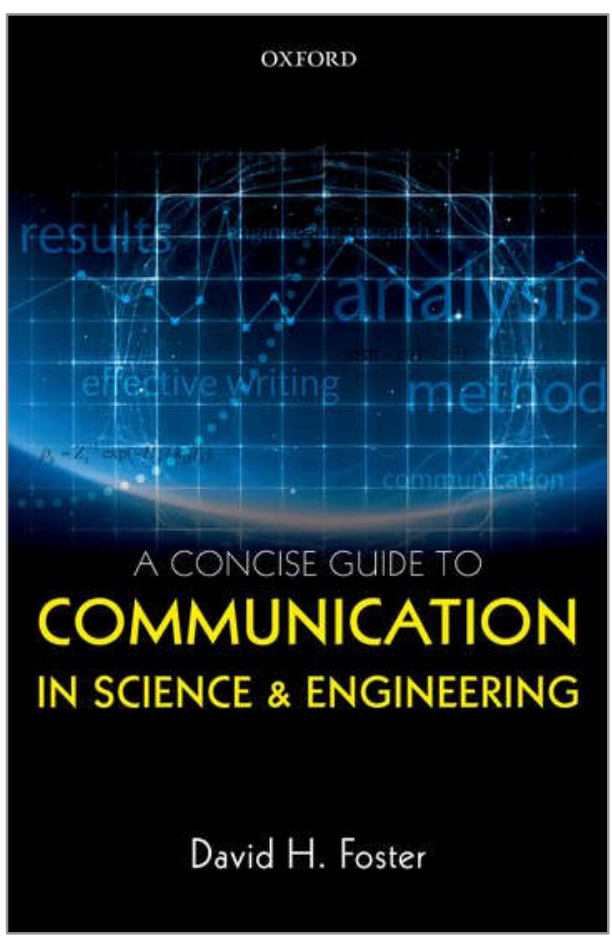
of research pa-

per. Secondly, there are more than 350 examples of good and bad practices in research paper writing and in the use of graphs and scientific language - these are showcased in grey boxes throughout the whole book for easy reference by the user.

Based on my experience - and in agreement with the author - I can recommend this book for all levels of researchers who wishing to undertake more effective scientific research and communication. It is a very practical book which is divided into chapters which are relevant to different stages of communication, e.g. preparation of illustrations or preparing posters, making it a useful and handy reference in todays world where communication is key.

\section{References}

Török P. 2016. Book Review: Heard, S.B. 2016. The scientist's guide to writing: How to write more easily and effectively throughout your scientific career. Bulletin of the Eurasian Dry Grassland Group 33: 30-30.

Mann, C.R. \& Twiss G.R. 1910. Physics. Scott, Foresman and Co. [Cited at the respective Wikipedia page on the subject https://en.wikipedia.org/wiki/If a tree falls in a forest]

Watt, A. 1947. Pattern and process in the plant community. Journal of Ecology 35: 1-22.

Péter Török, Debrecen, Hungary molinia@gmail.com 


\section{Recent Publications of our Members}

In this section, the contents of which will also be made available via our homepage, we want to facilitate an overview of grassland-related publications throughout Eurasia and to improve their accessibility. You are invited to send lists of such papers from the last three years following the format below to Iwona Dembicz, iwodem@op.pl. We will include your email address so that readers can request a pdf. For authors who own full copyright, we can also post a pdf on the EDGG homepage.

\section{Biodiversity}

Ambarlı, D., Vrahnakis, M., Burrascano, S., Naqinezhad, A., \& Pulido Fernández, M. 2018. Grasslands of the Mediterranean Basin and the Middle East and their management. In: Squires, V.R., Dengler, J., Feng, H. \& Hua, L. (eds.) Grasslands of the world: diversity, management and conservation, pp. 27-63. CRC Press, Boca Raton, US.

Lyons, A., Powell, I., Ashton, P.A. \& Oxbrough, A. 2018. Habitat associations of epigeal spiders in upland calcareous grassland landscapes: the importance for conservation. Biodiversity and Conservation 27: 12011219.

Lyons, A., Powell, I., Ashton, P.A. \& Oxbrough, A. 2018. Epigeal spider assemblage responses to vegetation structure under contrasting grazing management in upland calcareous grasslands. Insect Conservation and Diversity 11: 383-395.

Lyons, A., Ashton, P.A. \& Oxbrough, A. 2018. Managing biodiversity in upland calcareous grassland landscapes: a case study of spiders and ground beetles. Edge Hill University, Lancashire, UK. [Technical Report]

Török, P., Janišová, M., Kuzemko, A., Rūsiṇa S. \& Dajić Stevanović, Z. 2018. Grasslands, their threats and management in Eastern Europe. In: Squires, V.R., Dengler, J., Feng, H. \& Hua, L. (eds.) Grasslands of the world: diversity, management and conservation, pp. 64-88. CRC Press, Boca Raton, US.

\section{Conservation and restoration}

Boch, S., Müller, J., Prati, D. \& Fischer, M. 2018. Lowintensity management promotes bryophyte diversity in grasslands. Tuexenia 38: 311-328.

Boch, S., Allan, E., Humbert, J.-Y., Kurtogullari, Y., LessardTherrien, M., Müller, J., Prati, D., Rieder, N.S., Arlettaz, R. \& Fischer, M. 2018. Direct and indirect effects of land use on bryophytes in grasslands. Science of the Total Environment 644: 60-67.

Boch, S., Ginzler, C., Schmidt, B.R., Bedolla, A., Ecker, K., Graf, U., Küchler, H., Küchler, M., Holderegger, R. \& Bergamini, A. 2018. Wirkt der Schutz von Biotopen? Ein Programm zum Monitoring der Biotope von nationaler Bedeutung in der Schweiz. ANLiegen Natur 40: 39-48.

Deák, B., Becker, T., Boch, S. \& Wagner, V. 2018. Conservation, management and restoration of semi-natural and natural grasslands in Central Europe - Editorial to the 13th EDGG Special Feature. Tuexenia 38: 305-310.
Molnár V., Mészáros, A., Csathó, A.I., Balogh, G., Takács, A., Löki, V., Lovas-Kiss, Á., Tökölyi, J., Somlyay, L. \& Bauer, N. 2018. Distribution and seed production of the rare, dry grassland specialist Sternbergia colchiciflora (Amaryllidaceae) in Pannonian cemeteries. Tuexenia 38: 371-384.

Lyons, A., Powell, I., Ashton, P.A. \& Oxbrough, A. 2017. Impacts of contrasting grazing management on plants and carabid beetles in upland calcareous grasslands. Agriculture, Ecosystems \& Environment 244: 22-34.

\section{Ecology}

Heer, N., Klimmek, F., Zwahlen, C., Fischer, M., Hölzel, N., Klaus, V.H., Kleinebecker, T., Prati, D. \& Boch, S. 2018. Hemiparasite-density effects on grassland plant diversity, composition and biomass. Perspectives in Plant Ecology, Evolution and Systematics 32: 22-29.

\section{Contact persons: \\ Steffen Boch steffen.boch@wsl.ch András István Csathó csatho@verge.hu AshleyLyons Lyonsa@edgehill.ac.uk Péter Török molinia@gmail.com}

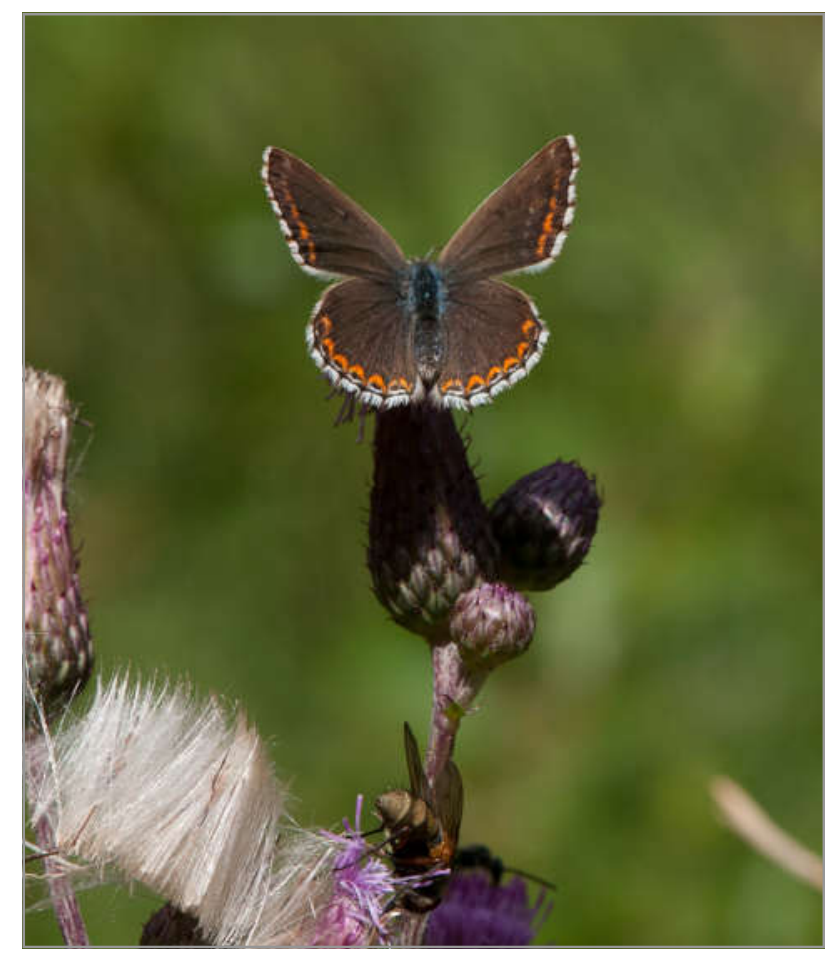

Female Polyommatus bellargus. Photo: J. Dengler. 


\section{Forthcoming Events}

9th Biennial Conference of the International Biogeography Society

8-12 January 2019 in Málaga, Spain

Abstract submission deadline: 26th September 2018, early registration deadline: 31st October 2018.

Conference website: https://www.biogeography.org/ meetings/ibsmalaga2019/

13th annual meeting of the Specialist Group Macroecology 11-14 March 2019 in Würzburg, Germany

Abstract submission deadline: 15 December 2018

Conference website: https://www.biozentrum.uniwuerzburg.de/cctb/research/ecosystem-modeling/events/ macroecology-2019/

\section{2nd meeting of the GfÖ-Specialist Group Plant Population (PopBio)}

23-25 May 2019 in Warsaw, Poland

\section{European Congress of Lepidopterology}

3-7 June 2019 in University of Molise, Campobasso, Italy Early registration deadline: March 15, 2019, abstract submission deadline: April 15, 2019.

Conference website: http://www.sel2019conference.com/

12th EDGG Field Workshop: Inneralpine dry valleys of Switzerland

11-19 May 2019, Switzerland

see details in Palaearctic Grasslands 38 on pp. 10-11

16th Eurasian Grassland Conference (EGC)

29 May - 5 June 2019 in Graz, Austria and Maribor, Slovenia see details in Palaearctic Grasslands 38 on pp. 8-9 13th EDGG Field Workshop: Grasslands of Armenia along the elevational gradient

26 June -7 July 2019, Armenia

see details in Palaearctic Grasslands 38 on pp. 10-11

10th International Association for Landscape Ecology (IALE) World Congress

1-5 July 2019 in Milan, Italy

Conference website: http://www.iale2019.unimib.it/

62nd Symposium of International Association for Vegetation Science (IAVS)

14-19 July 2019 in Bremen, Germany

\section{SCB's 29th International Congress for Conservation Biology (ICCB 2019)}

21-25 July 2019 in Kuala Lumpur, Malaysia

Conference website: https://conbio.org/mini-sites/iccb$\underline{2019 /}$

28th Workshop of European Vegetation Survey (EVS)

2-6 September 2019 in Madrid, Spain

\section{0th European Congress of Herpetology}

2-6 September 2019 in Milan, Italy

Conference website: http://seh-congress-2019.unipv.it/

\section{8th World Conference on Ecological Restoration}

22-27 September 2019 in Cape Town, South Africa

Conference website: https://ser2019.org/

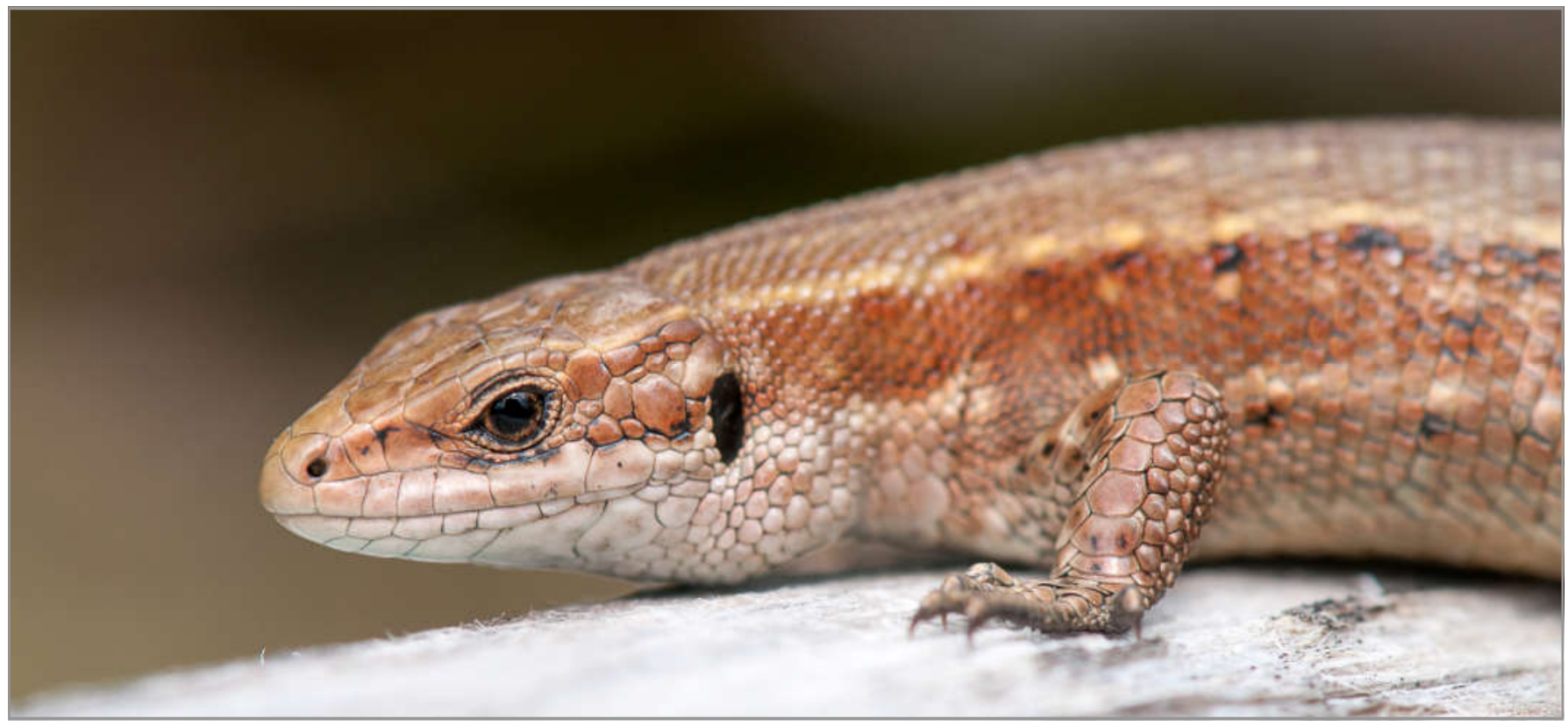

Viviparous lizard (Zootoca vivipara). Photo: J. Dengler. 


\section{eDGG}

Grass[a!nd]

research and conservation
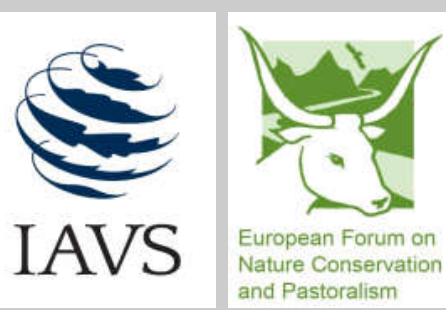

EDGG on the web:

http://www.edgg.org

EDGG in Facebook:

https://www.facebook.com/groups/938367279561202

EDGG on the ResearchGate

https://www.researchgate.net/project/EDGG-Eurasian-

The Eurasian Dry Grassland Group (EDGG), founded in 2008, is a working group of the International Association for Vegetation Science (IAVS) and member of the European Forum on Nature Conservation and Pastoralism (EFNCP). On 5 December 2018, it had 1333 members from 67 countries.

The Eurasian Dry Grassland Group (EDGG) is a network of researchers and conservationists interested in any type of Palaearctic natural and semi-natural grasslands. It is an official subgroup of IAVS (http://www.iavs.org) but one can join our group without being an IAVS member. We live from the activities of our members. Everybody can join the EDGG without any fee or other obligation.

The EDGG covers all aspects related to grasslands, in particular: plants - animals - fungi - microbia - soils - taxonomy - phylogeography - ecophysiology - population biology - species' interactions - vegetation ecology - syntaxonomy - landscape ecology - biodiversity - land use history - agriculture - nature conservation - restoration - environmental legislation - envi-

\section{EDGG Executive Committee and responsibilities of its members}

Didem Ambarlı, Turkey

didem.ambarli@gmail.com

Chief Editor of the Website; Deputy IAVS Representative and Treasurer; Deputy Conference Coordinator

Idoia Biurrun, Spain

idoia.biurrun@ehu.es

Membership Administrator; Deputy Chief Editor of Palaearctic Grasslands; Deputy Field Workshop Coordinator

Jürgen Dengler, Switzerland

juergen.dengler@uni-bayreuth.de

Coordinator for Special Features; Field Workshop Coordinator; Deputy Chief Editor of Palaearctic Grasslands

Anna Kuzemko, Ukraine

anyameadow.ak@gmail.com

Chief Editor of Palaearctic Grasslands; Facebook Group Administrator

\section{Péter Török, Hungary}

molinia@gmail.com

IAVS Representative and Treasurer; Deputy Coordinator for Special Features; member of the Editorial Board of Palaearctic Grasslands

\section{Stephen Venn, Finland}

Stephen.Venn@Helsinki.Fi

Secretary-General; Deputy Facebook Group Administrator; member of the Editorial Board of Palaearctic Grasslands

\section{Michael Vrahnakis, Greece}

mvrahnak@teilar.gr

Conference Coordinator

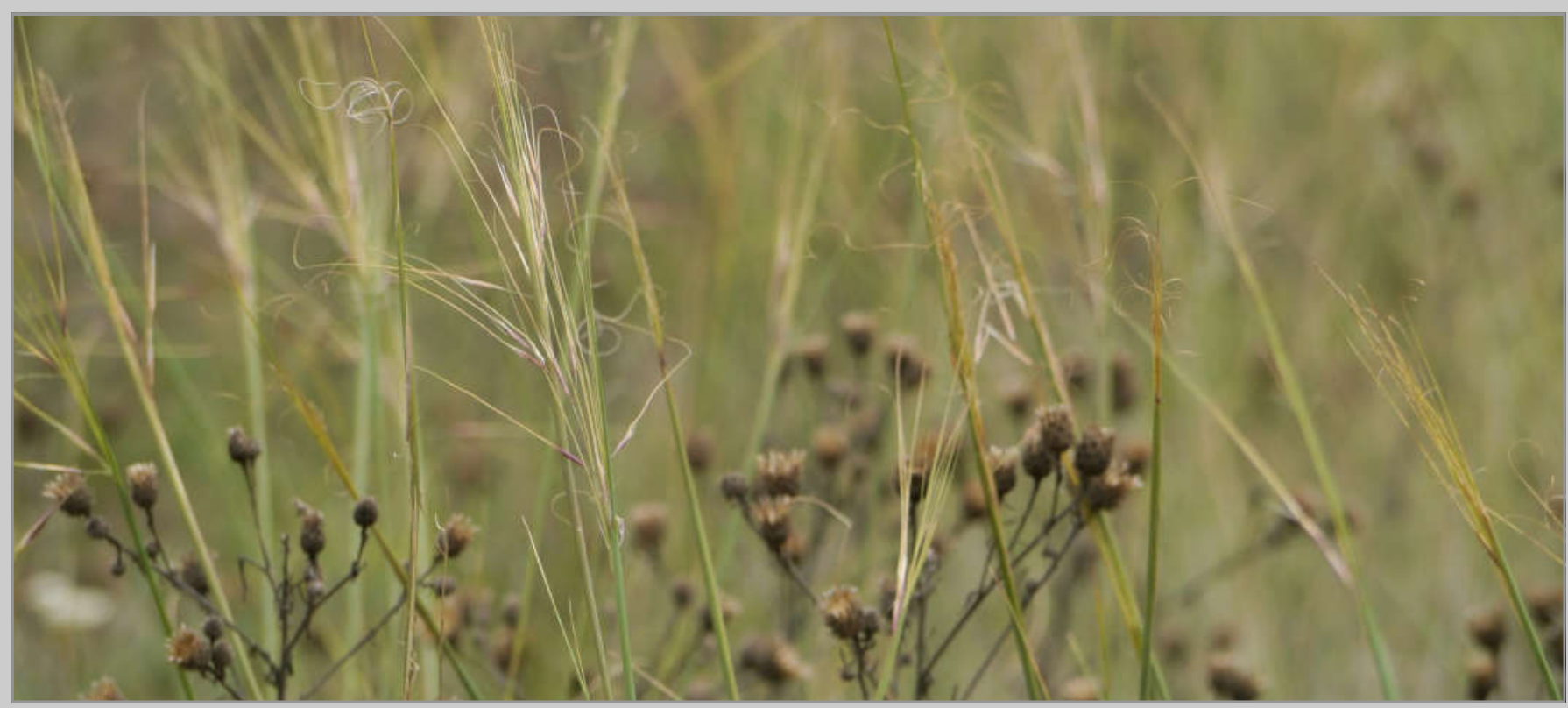

Late blooms of Stipa capillata and Centaurea stoebe in Góry Wschodnie nature reserve, Poland. Photo: I. Dembicz. 